\title{
MEDIA KOMUNIKASI PILIHAN KARYAWAN DALAM ALIRAN PESAN DARI ATASAN KE BAWAHAN (DOWNWARD COMMUNICATION)
}

\author{
Prida Ariani AA \\ Jurusan Ilmu Komunikasi, Fakultas Ilmu Komunikasi \\ Universitas Kristen Petra \\ Jalan Siwalankerto 121-131 Surabaya 60236 \\ email: pridaariani@peter.petra.ac.id
}

\begin{abstract}
In an organization, to ensure the succeed of an organizational communication, we need to have a good communication between superiors and subordinates (downward communication), but very often there are mixed communication in the lower level due to the incomplete information by the time a message reached the lower level employee. The usage of proper downward communication tools can help to minimize the downward filtering and mixed message. The communication tools that are used to send message from the upper level to lower level, whether it's oral or written are considered important additional facility for downward communication. This research is using qualitative approach with focus group discussion method. The research result indicates that in every type of downward communication which consist of task instruction, rational, ideology, information and feedback, the employees are using different downward communication tools with different reason or different encouragement factor of tools usage too.
\end{abstract}

Keywords: media communication, downward communication

\section{PENDAHULUAN}

Mutual understanding merupakan sebuah tujuan yang ingin dicapai organisasi ketika melakukan tindakan komunikasi. Dalam proses mencapai mutual understanding inilah komunikasi menjadi hal penting untuk mendukung proses penyampaian informasi dan pengertian dari satu orang ke orang lain. Oleh karena itu adanya kegiatan komunikasi menyebabkan ketidakmengertian (misunderstanding) di dalam suatu organisasi dapat dihindari dan meminimalkan terjadinya konflik antar individu dalam organisasi.

Komunikasi organisasi sendiri didefinisikan sebagai pertunjukan dan penafsiran pesan di antara unit-unit komunikasi yang merupakan bagian dari suatu organisasi tertentu. Suatu organisasi terdiri dari unit-unit komunikasi dalam hubungan-hubungan hierarkis antara yang satu dengan lainnya dan berfungsi dalam suatu lingkungan (Pace \& Faules, 2005, p.31). Jadi dalam komunikasi organisasi terjadi aliran pesan-pesan yang berorientasikan tujuan di antara sumber-sumber komunikasi, dalam suatu pola, dan melalui suatu medium atau media (Pareek, 1984, p.97). 
Aliran pesan dalam komunikasi organisasi dapat terjadi dari atasan ke bawahan (downward communication), yaitu informasi yang mengalir dari jabatan berotoritas lebih tinggi kepada mereka yang berotoritas lebih rendah (Pace \& Faules, 2002 , p.184). Komunikasi dalam organisasi terutama downward communication berhubungan dengan pencapaian tujuan kinerja organisasi. Komunikasi organisasi mendukung terlaksananya tujuan organisasi terutama peningkatan kinerja yang ditunjukkan dengan produktivitas yang tinggi.

Sementara bentuk aliran pesan yang kedua adalah upward communication, yaitu informasi yang mengalir dari tingkat yang lebih rendah (bawahan) ke tingkat yang lebih tinggi (penyelia). Aliran pesan yang lain adalah komunikasi horisontal, dan komunikasi diagonal. Komunikasi horisontal atau yang disebut juga komunikasi ke samping atau komunikasi mendatar atau sejajar, adalah proses penyampaian informasi yang melibatkan pegawai atau pimpinan yang masing-masing mempunyai level hirarki jabatan yang setingkat atau sejajar. Jadi pihak-pihak yang berkomunikasi berasal dari jenjang jabatan yang setara. Sementara komunikasi diagonal adalah proses penyampaian dan penerimaan informasi atau alur informasi yang berlangsung antara pegawai pada tingkat kedudukan yang berbeda, pada tugas atau fungsi yang berbeda dan satu sama lainnya tidak mempunyai wewenang langsung (Suranto, 2005, p.95).

Dalam penyelenggaraan komunikasi organisasi, arus komunikasi ke bawah lebih banyak digunakan daripada arus komunikasi ke atas. Dengan demikian pengendali komunikasi formal ini berada pada pihak yang secara struktural organisasi memiliki kedudukan yang lebih tinggi. Bahkan menurut Tubbs \& Moss (2000), downward communication biasanya diprakarsai oleh manajemen organisasi tingkat atas dan kemudian ke bawah melewati rantai perintah (p.174). Masih terkait dengan arus komunikasi ke bawah, apabila sebagian besar bersifat mendukung dan memiliki unsur perhatian yang besar terhadap bawahan maka rangkaian sifat akan lebih bersifat mendukung. Komunikasi seperti itu akan mendorong pembentukan kolaborasi antara pimpinan dan pegawai. Lebih jauh lagi, komunikasi yang terjadi akan mendorong rangkaian penuh komunikasi ke atas (Curtis, Floyd \& Winsor, 2004, p.25). Hal tersebut diperjelas oleh Tubbs \& Moss (2000) bahwa komunikasi atasan kepada bawahan merupakan komponen tunggal terpenting dalam keberhasilan komunikasi organisasional, namun penyimpangan pesan lebih banyak terjadi pada tingkat organisasi yang lebih bawah. Hal yang sama juga diungkapkan oleh Pareek (1984) bahwa banyak informasi yang hilang dalam komunikasi ke bawah. Agar informasi yang diberikan kepada bawahan dapat tersampaikan dengan baik maka dibutuhkan media untuk menyampaikan isi pesan tersebut. Wexley \& Yukie (2005) berpendapat bahwa dalam komunikasi ke bawah penggunaan media yang sesuai dapat membantu menurunkan penyaringan ke bawah dan penyimpangan pesan (p.96).

Media komunikasi sangat diperlukan dalam operasional kerja suatu kantor, karena media komunikasi dapat mempermudah penyampaian pesan, mengatasi hambatan-hambatan komunikasi baik dari segi ruang maupun waktu (Suranto, 2005, p.121). Media yang dipakai dalam komunikasi ke bawah yaitu atasan kepada bawahannya dapat berupa komunikasi lisan maupun tertulis. Wexley \& Yukie (2005) menambahkan media-media yang digunakan untuk menyampaikan informasi atasan kepada bawahannya ini baik metode lisan yaitu rapat/diskusi/seminar/ 
konferensi, wawancara, telepon, sistem interkom, kontak interpersonal, laporan lisan, ceramah maupun metode tulisan seperti surat, memo, telegram, majalah, surat kabar, deskripsi pekerjaan, panduan pelaksanaan pekerjaan, laporan tertulis dan pedoman kebijaksanaan adalah merupakan sarana tambahan yang penting bagi komunikasi ke bawah.

Dari sekian banyaknya media yang dapat digunakan dalam berkomunikasi dalam konteks organisasi, Walsh menyatakan bahwa "one of the basic principles of effective communication is not to rely on one method of communication. Several tools are often used for one audience" (1986, p.153). Pertimbangan penggunaan media komunikasi seringkali dilakukan berdasarkan karakteristik yang dimiliki oleh masing-masing media. Pada media lisan penggunaannya seringkali dilakukan karena pertimbangan adanya umpan balik langsung, sederhana dan mudah, tidak memerlukan catatan permanen, mengumpulkan pendengar dengan mudah dan ekonomis serta mendorong interaksi untuk memecahkan masalah atau mencapai keputusan. Sementara penggunaan media komunikasi tulisan didasarkan pada karakteristik seperti informasinya kompleks, catatan permanen diperlukan untuk rujukan di masa depan, penerimanya banyak dan tersebar secara geografis dan interaksi langsung dengan penerima tidak penting atau tidak diinginkan (Bovée \& Thill, 2005).

Sementara media komunikasi baik lisan maupun tulisan yang digunakan oleh atasan kepada bawahan dalam memberikan informasi tugas atau downward communication dapat diklasifikasikan menjadi lima tipe yaitu memberikan informasi terkait instruksi tugas, rasional, ideologi, informasi dan balikan adalah penting untuk mendukung kelancaran komunikasi ke bawah. Yang dimaksud dengan instruksi tugas adalah pesan yang disampaikan kepada bawahan mengenai apa yang diharapkan dilakukan mereka dan bagaimana melakukannya. Pesan itu mungkin bervariasi seperti perintah langsung, deskripsi tugas, prosedur manual, program latihan tertentu, alat-alat bantu melihat dan mendengar yang berisi pesan-pesan tugas dan sebagainya. Sementara pengertian rasional adalah pesan yang menjelaskan mengenai tujuan aktivitas dan bagaimana kaitan aktivitas itu dengan aktivitas lain dalam organisasi atau objektif organisasi. Ideologi adalah pesan yang merupakan perluasan pesan rasional. Dimana pesan rasional penekanannya pada penjelasan tugas dan kaitannya dengan perspektif organisasi. Sedangkan pada pesan ideologi sebaliknya mencari sokongan dan antusias dari anggota organisasi guna memperkuat loyalitas, moral dan motivasi. Pesan informasi dimaksudkan untuk memperkenalkan bawahan dengan praktik-praktik organisasi, peraturan-peraturan organisasi, keuntungan, kebiasaan dan data lain yang tidak berhubungan dengan instruksi dan rasional, misalnya buku handbook dari karyawan adalah contoh dari pesan informasi. Dan balikan adalah pesan yang berisi informasi mengenai ketepatan individu dalam melakukan pekerjaannya (Wexley dan Yukie, 2005).

Semua bentuk komunikasi ke bawah tersebut dipengaruhi oleh struktur hirarki dalam suatu organisasi. Pesan ke bawah cenderung bertambah karena pesan itu bergerak melalui tingkatan hirarki secara berturut-turut. Karyawan menginginkan informasi dari atasannya dan mencari instruksi dan pekerjaannya, informasi yang berkenaan dengan hal-hal yang mempengaruhi mereka dan berita-berita yang terbaru. Walaupun informasi yang mereka peroleh bertambah mereka masih mencari informasi tambahan (Muhammad, 2004, p.110). 
Klasifikasi informasi tugas atau downward communication menjadi lima tipe menurut Wexley dan Yukie ini digarisbawahi oleh Suprihanto, Harsiwi \& Hadi (2003, p.86) yang mengatakan bahwa komunikasi ke bawah biasanya bertujuan untuk memberikan pengarahan-pengarahan atau instruksi kerja tertentu, memberikan informasi mengapa suatu pekerjaan harus diselesaikan, memberikan informasi tentang prosedur dan praktek-praktek organisasional, memberikan umpan balik prestasi karyawan, dan menyediakan informasi mengenai aspek ideologi dalam membantu organisasi dalam menanamkan pengertian tentang tujuan yang ingin dicapai.

\section{RUMUSAN MASALAH}

Manakah media komunikasi yang dipilih karyawan organisasi/korporasi dalam aliran pesan dari atasan ke bawahan (downward communication)?

\section{BATASAN PENELITIAN}

1. Media komunikasi lisan hanya dibatasi pada penggunaan rapat, telepon, kontak interpersonal, laporan lisan, dan ceramah sementara media tulisan dibatasi hanya pada penggunaan surat, deskripsi pekerjaan, laporan tertulis, dan pedoman kebijaksanaan.

2. Jenis penelitian yang digunakan adalah deskriptif kuantitatif artinya, penelitian ini bertujuan untuk membuat deskripsi secara sistematis, faktual, dan akurat tentang fakta-fakta dan sifat-sifat populasi atau objek tertentu. Dalam hal ini yaitu faktor-faktor yang mendorong karyawan dalam menggunakan media komunikasi pada downward communication. Penelitian deskriptif kuantitatif hanya menggambarkan, meringkaskan berbagai kondisi, situasi atau variabel, tanpa melihat hubungan-hubungan yang ada (Bungin, 2001, p.33).

3. Sementara metode penelitian yang dipilih adalah Focus Group Discussion (FGD) pada karyawan sebuah organisasi bisnis, yaitu organisasi yang bergerak dalam bidang usaha baik jasa maupun non-jasa, baik yang memiliki jabatan sebagai atasan, menengah, maupun bawahan.

\section{PEMBAHASAN}

\section{Temuan Penelitian}

Selama penelitian dilakukan, FGD diselenggarakan dalam 7 hari dengan 1 grup yang berdiskusi setiap harinya. Setiap kelompoknya dihadiri oleh 8-12 orang dan diskusi dilakukan selama \pm 2 jam mulai pukul 18.00-20.00 WIB. Temuan penelitian yang didapat terkait dengan topik "media komunikasi pilihan karyawan pada downward communication" adalah sebagai berikut: 
Tabel 1. Media Komunikasi Lisan pada Downward Communication untuk Tujuan Instruksi Tugas yang Dipilih dan Tidak Dipilih Karyawan

\begin{tabular}{|c|c|c|c|}
\hline Tujuan & $\begin{array}{l}\text { Peringkat } \\
\text { media }\end{array}$ & Nama media & Alasan \\
\hline \multirow[t]{5}{*}{ Pendelegasian tugas } & \multicolumn{2}{|c|}{$\begin{array}{l}\text { Media yang Telepon } \\
\text { dipilih }\end{array}$} & $\begin{array}{l}\text { Umpan balik } \\
\text { Singkat dan mudah } \\
\text { Tidak memerlukan catatan } \\
\text { permanen }\end{array}$ \\
\hline & & Rapat & $\begin{array}{l}\text { Bersama-sama dan cepat } \\
\text { Interaksi antar karyawan }\end{array}$ \\
\hline & \multicolumn{2}{|c|}{$\begin{array}{l}\text { Media yang Laporan lisan } \\
\text { tidak } \\
\text { dipilih }\end{array}$} & $\begin{array}{l}\text { Umpan balik } \\
\text { Singkat dan mudah } \\
\text { Tidak memerlukan catatan } \\
\text { permanen }\end{array}$ \\
\hline & & $\begin{array}{l}\text { Kontak } \\
\text { interpersonal }\end{array}$ & Bersama-sama dan cepat \\
\hline & & Telepon & Interaksi antar karyawan \\
\hline \multirow[t]{5}{*}{ Pengarahan tugas } & \multicolumn{2}{|c|}{$\begin{array}{l}\text { Media yang Telepon } \\
\text { dipilih }\end{array}$} & $\begin{array}{l}\text { Umpan balik } \\
\text { Singkat dan mudah } \\
\text { Tidak memerlukan catatan } \\
\text { permanen }\end{array}$ \\
\hline & & Rapat & $\begin{array}{l}\text { Bersama-sama dan cepat } \\
\text { Interaksi antar karyawan }\end{array}$ \\
\hline & \multicolumn{2}{|c|}{$\begin{array}{l}\text { Media yang Laporan lisan } \\
\text { tidak } \\
\text { dipilih }\end{array}$} & $\begin{array}{l}\text { Umpan balik } \\
\text { Singkat dan mudah } \\
\text { Tidak memerlukan catatan } \\
\text { permanen }\end{array}$ \\
\hline & & $\begin{array}{l}\text { Kontak } \\
\text { interpersonal }\end{array}$ & Bersama-sama dan cepat \\
\hline & & Telepon & Interaksi antar karyawan \\
\hline
\end{tabular}

Sumber: Data Primer, Panduan Pertanyaan

Hasil di atas menunjukkan bahwa media komunikasi yang dipilih karyawan dalam downward communication untuk tujuan instruksi tugas adalah:

a. Telepon, karena adanya umpan balik, singkat dan mudah, serta tidak memerlukan catatan permanen.

b. Rapat, karena dapat menjangkau banyak karyawan dan dilakukan dengan cepat; dan dapat mendorong interaksi antar karyawan sehingga dapat membantu memecahkan masalah.

Sementara itu, media yang tidak dipilih adalah:

a. Laporan lisan, dengan alasan tidak dapat dilakukan dengan singkat dan mudah, tidak mudah mendapatkan umpan balik dari karyawan, dan bukan berarti tidak memerlukan catatan permanen. 
b. Kontak interpersonal, dengan alasan bahwa media ini tidak dapat menjangkau sejumlah karyawan yang dimaksud sehingga tidak dapat menyampaikan instruksi tugas dengan cepat.

c. Telepon, dengan alasan tidak dapat mendorong interaksi antar karyawan sehingga karyawan dapat memecahkan permasalahan secara bersama-sama.

Hasil temuan penelitian di atas menunjukkan bahwa media komunikasi pada downward communication yang dipilih karyawan dalam rangka tujuan pesan instruksi tugas adalah telepon dan rapat. Hasil ini menunjukkan bahwa telepon merupakan media komunikasi yang paling tepat digunakan dalam menyampaikan instruksi tugas kepada karyawan, hal ini disebabkan dengan menggunakan telepon maka atasan dapat menerima umpan balik dari bawahan secara langsung, dapat digunakan dengan mudah dan memerlukan waktu yang singkat, dan tidak memerlukan catatan permanen. Hasil ini sesuai dengan kelebihan yang dimiliki oleh telepon yaitu bahwa telepon adalah media yang efektif karena masih ada kesempatan untuk mendapatkan umpan balik langsung, klarifikasi dan tindakan dari orang yang diajak bicara (Walsh, 1986, p.168). Pendapat tersebut didukung oleh Suranto (2005) bahwa, "telepon merupakan media yang sangat praktis untuk proses menyampaikan dan menerima pesan lisan di kalangan pegawai maupun pejabat di suatu perkantoran" (p.125).

Tetapi penelitian juga menemukan bahwa telepon bukan merupakan media yang paling disarankan untuk digunakan apabila tujuan instruksi tugas tersebut adalah untuk mendorong interaksi antar karyawan sehingga karyawan dapat memecahkan permasalahan secara bersama-sama. Hal ini disebabkan karena meskipun penggunaan media telepon memiliki dampak positif seperti, meningkatkan efisiensi dan produktivitas, mempermudah pengiriman dan penerimaan informasi, mengurangi kekakuan struktur birokrasi, dan memungkinkan terjadinya desentralisasi pengambilan keputusan; akan tetapi penggunaan media telepon juga memiliki dampak negatif yaitu para anggota perkantoran kehilangan kesempatan untuk saling berkomunikasi secara interpersonal (Suranto, 2005, p.130-131).

Selain telepon, media yang dipilih karyawan berkaitan dengan penyampaian instruksi tugas adalah rapat, di mana rapat merupakan pilihan yang tepat untuk mendelegasikan tugas jika atasan ingin menjangkau karyawan dalam jumlah banyak dan cepat; dan dapat mendorong interaksi antar karyawan sehingga dapat membantu memecahkan masalah. Hal ini karena rapat memiliki beberapa kelebihan, di antaranya adalah:

a. Rapat menyatukan orang, memberi peluang untuk berbicara maupun untuk mendengarkan, suatu komunikasi dua arah. Rapat juga berguna untuk menyatukan kelompok kerja untuk rapat dan diskusi pemecahan masalah (Cultip et.al., 2005, p.233-234).

b. Rapat dapat dijadikan sebagai media komunikasi untuk menyampaikan informasi secara cepat dan tepat, dan dapat segera diketahui umpan baliknya (Suranto, 2005, p.125).

c. Rapat melibatkan seluruh anggota perkantoran tanpa melihat posisi atau jabatan (Suranto, 2005, p.129).

Sementara itu, media yang tidak dipilih adalah laporan lisan, dengan alasan tidak dapat dilakukan dengan singkat dan mudah, tidak mudah mendapatkan 
umpan balik dari karyawan, dan bukan berarti tidak memerlukan catatan permanen. Hasil ini menunjukkan bahwa meskipun laporan lisan memiliki peluang untuk terjadinya interaksi antara pembicara dengan pendengar (Bovée \& Thill, 2003, p.55), tetapi laporan lisan biasanya hanya memiliki kisaran penyampaian informasi yang sempit, didiskusikan dengan singkat dan kemudian dibuang begitu saja (Wilcox, 2005, p.420). Apalagi, di dalam menyampaikan laporan lisan, pihak penyampai laporan lisan juga harus mempersiapkan beberapa hal sesuai dengan tujuannya yaitu akurat, lengkap, dan tidak bias (Bovée \& Till, 2002, p.476).Media lain yang tidak dipilih dalam menyampaikan instruksi tugas adalah kontak interpersonal, dengan alasan bahwa media ini tidak dapat menjangkau sejumlah karyawan yang dimaksud sehingga tidak dapat menyampaikan instruksi tugas dengan cepat.

Tabel 2. Media Komunikasi Lisan pada Downward Communication untuk Tujuan Rasional yang Dipilih dan Tidak Dipilih Karyawan

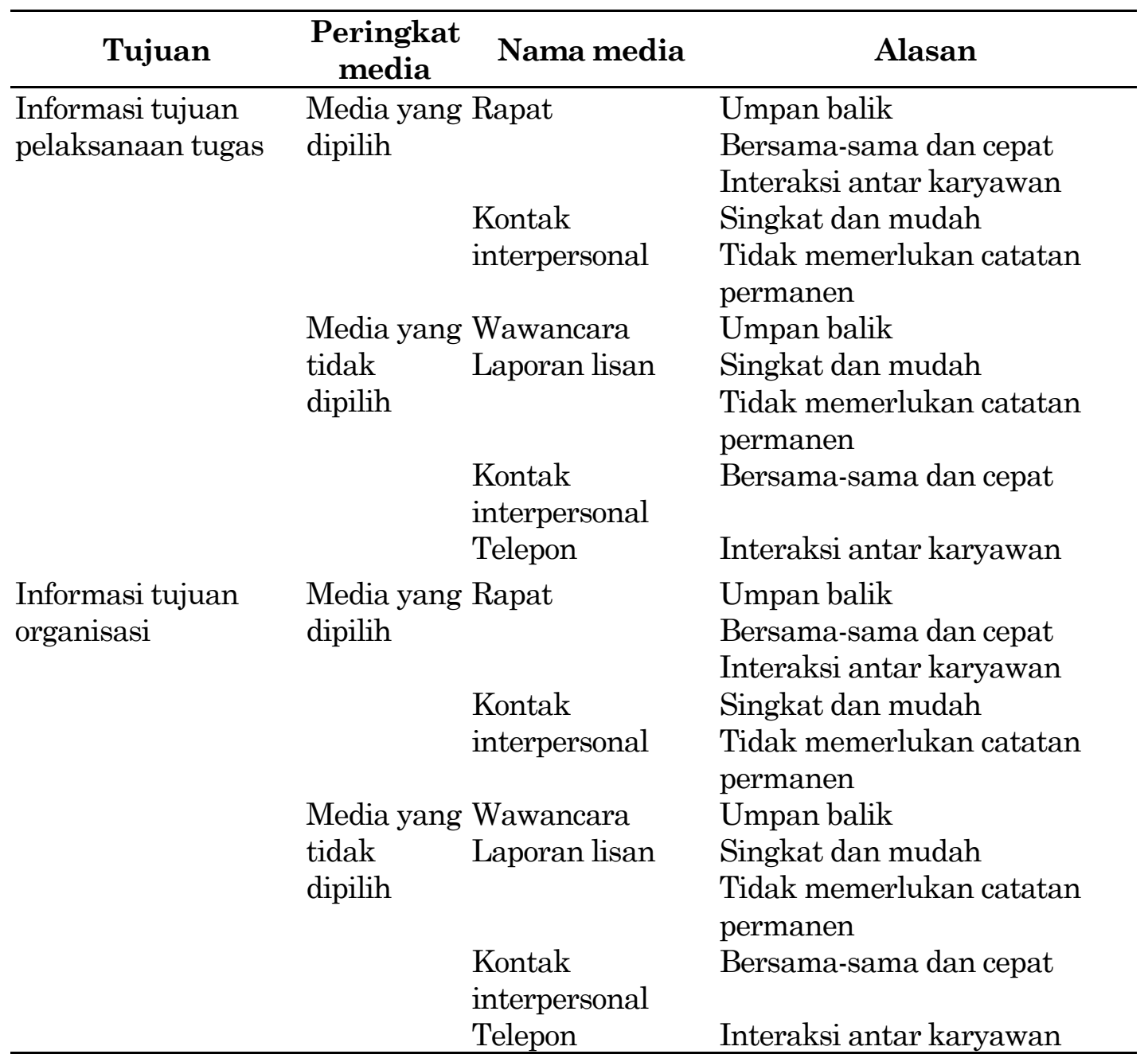

Sumber: Data Primer, Panduan Pertanyaan 
Temuan penelitian di lapangan menunjukkan bahwa media komunikasi yang dipilih karyawan dalam downward communication untuk tujuan rasional adalah:

a. Rapat, dengan alasan dapat memperoleh umpan balik secara langsung dari bawahan; dapat menjangkau banyak karyawan dan dilakukan dengan cepat; dan dapat mendorong interaksi antar karyawan sehingga dapat membantu memecahkan masalah.

b. Kontak interpersonal, dengan alasan singkat dan mudah, serta tidak memerlukan catatan permanen.

Sementara itu, media komunikasi yang tidak dipilih untuk digunakan:

a. Laporan lisan, dengan alasan tidak dapat dilakukan dengan singkat dan mudah dan bukan berarti tidak memerlukan catatan permanen karena pesan rasional sangat membutuhkan catatan permanen.

b. Kontak interpersonal, dengan alasan bahwa media ini tidak dapat menjangkau sejumlah karyawan yang dimaksud sehingga tidak dapat menyampaikan instruksi tugas dengan cepat.

c. Telepon dengan alasan tidak dapat mendorong interaksi antar karyawan sehingga karyawan dapat memecahkan permasalahan secara bersama-sama.

d. Wawancara dengan alasan umpan balik karena membatasi pilihan jawaban bagi orang yang diwawancarai.

Dari hasil temuan penelitian di atas menunjukkan bahwa media downward communication yang dipilih karyawan untuk penyampaian pesan rasional adalah rapat dan kontak interpersonal. Alasan yang dikemukakan oleh karyawan adalah bahwa melalui rapat maka akan dapat memperoleh umpan balik secara langsung dari bawahan; dapat menjangkau banyak karyawan dan dilakukan dengan cepat; dan dapat mendorong interaksi antar karyawan sehingga dapat membantu memecahkan masalah. Hal ini karena pesan rasional merupakan pesan yang menjelaskan mengenai tujuan aktivitas dan bagaimana kaitan aktivitas itu dengan aktivitas lain dalam organisasi atau objektif organisasi. Kualitas dan kuantitas dari komunikasi rasional ditentukan oleh filosofi dan asumsi pimpinan mengenai bawahannya. Bila atasan menganggap bawahannya pemalas, atau hanya mau bekerja bila dipaksa maka pimpinan memberikan pesan yang bersifat rasional ini sedikit. Tetapi apabila pimpinan menganggap bawahannya orang yang dapat memotivasi diri sendiri dan produktif, maka biasanya diberikan pesan rasional yang banyak (Muhammad, 2005, p.108-110). Dengan demikian, rapat dapat dikatakan sebagai media yang tepat untuk menyampaikan pesan-pesan rasional yang perlu melibatkan banyak karyawan, mendorong interaksi antar karyawan, dan mendapatkan umpan balik dari karyawan secara langsung, di mana melalui rapat maka atasan dapat melihat secara langsung respon (kualitas fisik dan psikologis) bawahannya.

Lebih lanjut dikatakan media rapat dipilih karyawan pada saat:

a. Pimpinan perusahaan ingin menyampaikan pesan rasional yaitu tujuan pelaksanaan tugas dan tujuan organisasi. Sebagaimana diungkapkan oleh salah seorang responden bahwa dengan media rapat penyampaian tujuan pelaksanaan tugas tersebut akan langsung dapat diterima oleh banyak karyawan sekaligus sehingga menghemat waktu dan tenaga. Responden tersebut juga menambahkan bahwa pada saat pelaksanaan rapat tersebut biasanya atasan akan dapat langsung menerima umpan balik dari karyawan mengenai informasi yang disampaikan, sehingga dapat diketahui apakah karyawan telah memahami pesan rasional 
yang disampaikan. Umpan balik yang diberikan dapat berupa masukan maupun pertanyaan dari karyawan berkaitan dengan topik yang dikemukakan dalam rapat.

b. Untuk koordinasi divisi/departemen, manajer akan mengumpulkan anggota divisinya guna menginformasikan pesan rasional agar dipahami dan dimengerti. Manajer akan memanfaatkan kesempatan ini untuk menyampaikan pesan rasional dari perusahaan

Sementara itu, untuk media downward communication kontak interpersonal, faktor pendorong dipilihnya media tersebut adalah singkat dan mudah, serta tidak memerlukan catatan permanen. Hal ini karena kontak interpersonal merupakan jenis komunikasi one to one yang tidak membutuhkan persiapan untuk melakukan pertemuan. Artinya, kontak interpersonal dapat dilakukan kapan saja dan di mana saja ketika atasan ingin menginformasikan tujuan pelaksanaan tugas secara singkat dan mudah. Sebagaimana diutarakan oleh O'Rourke (2001) bahwa sejumlah informasi kadang-kadang mengalami perubahan dan dikonfirmasikan melalui berbagai lingkungan yang informal. Di mana biasanya seorang manajer akan menemukan informasi tersebut secara lisan baik melalui tatap muka di kantor, di tempat parkir, di lokasi olah raga, di cafetaria, di ruang konferensi, dan lain-lain (p.7). Karakteristik kontak interpersonal yang mendukung adalah bahwa karakteristik pesannya dua arah (two ways communication) yaitu dapat melibatkan emosi pendengar dalam upaya membangun suatu pengaruh, pendidikan, pengenalan, pengertian atau pemahaman (Ruslan, 2002, p.204). Dengan demikian, kontak interpersonal memang tepat untuk dijadikan sebagai media bagi atasan untuk menyampaikan tujuan pelaksanaan tugas tanpa menggunakan catatan permanen, di mana atasan dapat melakukannya di mana saja baik secara formal maupun informal (di saat-saat insidental). Sebagaimana dikatakan oleh salah seorang responden bahwa kontak interpersonal tidak mungkin akan dapat digunakan untuk menjangkau banyak karyawan sekaligus, akan tetapi jenis komunikasi ini sangat simpel dan mudah dilakukan. Apalagi, kontak interpersonal tidak menonjolkan formalitas sehingga atasan dapat menyampaikan informasi apapun yang diinginkan baik yang berkaitan dengan pekerjaan maupun tidak. Pembicaraan ini terjadi begitu saja tanpa ada persiapan formal terlebih dahulu dari atasan sehingga pembicaraan terkesan luwes dan bertukar pendapat tanpa mengharuskan adanya bukti.

Meskipun demikian, kontak interpersonal juga bukan merupakan media yang digunakan untuk menyampaikan pesan rasional karena media ini tidak dapat menjangkau sejumlah karyawan yang dimaksud sehingga tidak dapat menyampaikan instruksi tugas dengan cepat. Sebagaimana dikatakan oleh salah seorang respoden bahwa kontak interpersonal tidak mungkin akan dapat digunakan untuk menjangkau banyak karyawan sekaligus, akan tetapi jenis komunikasi ini sangat simpel dan mudah dilakukan. Apalagi, kontak interpersonal tidak menonjolkan formalitas sehingga atasan dapat menyampaikan informasi apapun yang diinginkan baik yang berkaitan dengan pekerjaan maupun tidak.

Sementara itu, media yang tidak dipilih karyawan lainnya adalah laporan lisan, telepon, dan wawancara. Laporan lisan, dengan alasan tidak dapat dilakukan dengan singkat, mudah, serta mudah juga untuk dibung begitu saja (Wilcox, 2005, p.420) dan tidak ada catatan permanen. Telepon dengan alasan tidak dapat mendorong interaksi antar karyawan sehingga karyawan dapat memecahkan permasalahan secara bersama-sama, selain itu pembicaraan melalui telepon mencipta- 
kan jurang artidisial antara atasan dan bawahan (Jefkins, 1992, p.175) dan wawancara dengan alasan umpan balik yang membatasi pilihan jawaban bagi orang yang diwawancarai karena pada awal interaksi pewawancara menetapkan tujuan situasi, sementara itu dalam wawancara tidak ada pihak yang memiliki kendali eksklusif terhadap situasi komunikasi (Curtis, Floyd \& Winsor, 2004, p.87).

Tabel 3. Media Komunikasi Lisan pada Downward Communication untuk Tujuan Ideologi yang Dipilih dan Tidak Dipilih Karyawan

\begin{tabular}{|c|c|c|c|}
\hline Tujuan & $\begin{array}{l}\text { Peringkat } \\
\text { media }\end{array}$ & Nama media & Alasan \\
\hline \multirow{9}{*}{$\begin{array}{l}\text { Mengembangkan } \\
\text { rasa memiliki } \\
\text { tugas } \\
\text { partisipasi } \\
\text { karyawan }\end{array}$} & \multirow{5}{*}{$\begin{array}{l}\text { Media } \\
\text { paling } \\
\text { digunakan }\end{array}$} & \multirow[t]{3}{*}{ Rapat } & Umpan balik \\
\hline & & & Bersama-sama dan cepat \\
\hline & & & Interaksi antar karyawan \\
\hline & & \multirow{2}{*}{$\begin{array}{l}\text { Kontak } \\
\text { interpersonal }\end{array}$} & Singkat dan mudah \\
\hline & & & $\begin{array}{l}\text { Tidak memerlukan catatan } \\
\text { permanen }\end{array}$ \\
\hline & \multirow{4}{*}{$\begin{array}{l}\text { Media } \\
\text { tidak } \\
\text { dipilih }\end{array}$} & Laporan lisan & $\begin{array}{l}\text { Singkat dan mudah } \\
\text { Tidak memerlukan catatan } \\
\text { permanen }\end{array}$ \\
\hline & & $\begin{array}{l}\text { Kontak } \\
\text { interpersonal }\end{array}$ & Bersama-sama dan cepat \\
\hline & & Telepon & Umpan balik \\
\hline & & Wawancara & Interaksi antar karyawan \\
\hline \multirow{10}{*}{$\begin{array}{l}\text { Menginformasikan } \\
\text { tugas dengan } \\
\text { memberikan } \\
\text { motivasi }\end{array}$} & \multirow{5}{*}{$\begin{array}{l}\text { Media } \\
\text { yang } \\
\text { dipilih }\end{array}$} & Rapat & Umpan balik \\
\hline & & & Bersama-sama dan cepat \\
\hline & & & Interaksi antar karyawan \\
\hline & & Kontak & Singkat dan mudah \\
\hline & & interpersonal & $\begin{array}{l}\text { Tidak memerlukan catatan } \\
\text { permanen }\end{array}$ \\
\hline & \multirow{5}{*}{$\begin{array}{l}\text { Media } \\
\text { tidak } \\
\text { dipilih }\end{array}$} & Laporan lisan & Singkat dan mudah \\
\hline & & & $\begin{array}{l}\text { Tidak memerlukan catatan } \\
\text { permanen }\end{array}$ \\
\hline & & $\begin{array}{l}\text { Kontak } \\
\text { interpersonal }\end{array}$ & Bersama-sama dan cepat \\
\hline & & Telepon & Umpan balik \\
\hline & & & Interaksi antar karyawan \\
\hline
\end{tabular}

Sumber: Data Primer, Panduan Pertanyaan

Hasil di atas menunjukkan bahwa media yang paling banyak digunakan oleh atasan dalam pelaksanaan downward communication untuk tujuan ideologi adalah:

a. Rapat, karena melalui rapat dapat memperoleh umpan balik secara langsung dari bawahan; dapat menjangkau banyak karyawan dan dilakukan dengan cepat; dan dapat mendorong interaksi antar karyawan sehingga dapat membantu memecahkan masalah.

b. Kontak interpersonal, dengan faktor pendorong singkat dan mudah, serta tidak memerlukan catatan permanen. 
Sementara itu, media yang paling tidak disarankan untuk digunakan adalah:

a. Laporan lisan, dengan alasan tidak dapat dilakukan dengan singkat dan mudah dan bukan berarti tidak memerlukan catatan permanen.

b. Kontak interpersonal, dengan alasan bahwa media ini tidak dapat menjangkau sejumlah karyawan yang dimaksud sehingga tidak dapat memberikan pesan ideologi dengan cepat.

c. Telepon dengan alasan tidak ada umpan balik secara langsung, tidak dapat mendorong interaksi antar karyawan sehingga karyawan dapat memecahkan permasalahan secara bersama-sama.

d. Wawancara dengan alasan tidak dapat mendorong interaksi antar karyawan.

Hasil temuan penelitian di atas menunjukkan bahwa media komunikasi pada downward communication yang dipilih karyawan dalam rangka tujuan pesan ideologi adalah rapat dan kontak interpersonal. Alasan yang dikemukakan oleh karyawan adalah bahwa melalui rapat maka akan dapat memperoleh umpan balik secara langsung dari bawahan; dapat menjangkau banyak karyawan dan dilakukan dengan cepat; dan dapat mendorong interaksi antar karyawan sehingga dapat membantu memecahkan masalah.

Berdasarkan diskusi lebih lanjut, media rapat biasanya digunakan pada saat:

a. Kesempatan ini untuk menyampaikan pesan yang dapat membangun semangat dan tanggung jawab. Melalui media rapat atasan berusaha untuk menggali kesulitan para karyawan dalam mengembangkan tugas dan partisipasinya.

b. Dalam rapat tersebut biasanya atasan akan dapat langsung menerima umpan balik dari karyawan mengenai informasi yang disampaikan, sehingga dapat diketahui apakah karyawan telah memahami tujuan pelaksanaan tugasnya masing-masing. Umpan balik tersebut dapat berupa masukan maupun pertanyaan dari karyawan berkaitan dengan topik yang dikemukakan dalam rapat.

c. Atasan dapat melakukan pengukuran loyalitas yang dapat diketahui dari penjabaran tugas atas pelaksanaan tugas yang diberikan atasan kepada karyawan.

d. Menyampaikan pesan perintah pengembangan tugas dan partisipasi karyawan dari atasan. Rapat dapat dimanfaatkan untuk menyampaikan strategi apa yang harus diambil agar pengunjung mal tempat pameran diadakan menjadi tertarik dengan penawaran yang diberikan dengan pembicaraan yang tidak bertele-tele dan cepat pada pokok permasalahan.

Selain rapat, media yang dipilih karyawan untuk menyampaikan pesan ideologi adalah kontak interpersonal karena media lisan ini singkat dan mudah dalam penyampaiannya dan tidak memerlukan catatan permanen. Hal ini juga dikarenakan oleh sifat dari kontak interpersonal itu sendiri yaitu:

a. Pesannya dua arah (two ways communication) yaitu dapat melibatkan emosi pendengar dalam upaya membangun suatu pengaruh, pendidikan, pengenalan, pengertian atau pemahaman (Ruslan, 2002, p.204).

b. Alat komunikasi yang paling efektif dan diinginkan oleh karyawan (Tucker, Derelian \& Rouner, 1997, p.237).

c. Karyawan dipanggil untuk mendapatkan interaksi yang lebih dengan supervisor dan pembuat keputusan (Tucker, Derelian \& Rouner, 1997, p.237).

Pesan ideologi yang disampaikan melalui kontak interpersonal bertujuan untuk membangun keakraban dengan bawahan. Jika atasan dan bawahan mampu menjalin keakraban maka pesan yang disampaikan dapat diterima dengan mudah. 
Sebagaimana dikatakan oleh salah seorang responden bahwa dengan menyampaikan pesan secara langsung maka karyawan akan menjadi lebih mudah menangkap pesan yang disampaikan oleh atasan. Selain itu, kontak interpersonal dengan atasan membuat bawahan menjadi lebih dihargai serta dapat membangun keakraban dengan bawahan. Jika atasan dan bawahan mampu menjalin keakraban maka pesan yang disampaikan dapat diterima dengan mudah. Selain itu dengan kontak personal atasan dapat mengetahui motivasi dan dapat memotivasi karyawan sehingga diperlukan suatu pendekatan yang lebih besar dibandingkan dengan telepon. Apalagi motivasi lebih banyak mengandung unsur psikologis sehingga memerlukan kejelian atasan untuk mengembangkannya. Selain itu penggunaan media kontak personal dapat menghilangkan ketegangan sehingga tujuan untuk memotivasi pun menjadi mudah untuk dilakukan.

Sementara itu media komunikasi lisan yang paling tidak disarankan untuk digunakan lainnya adalah laporan lisan dan wawancara.

Tabel 4. Media Komunikasi Lisan pada Downward Communication untuk Tujuan Informasi yang Dipilih dan Tidak Dipilih Karyawan

\begin{tabular}{|c|c|c|c|}
\hline Tujuan & $\begin{array}{l}\text { Peringkat } \\
\text { media }\end{array}$ & Nama media & Alasan \\
\hline \multirow{10}{*}{$\begin{array}{l}\text { Menginformasika } \\
\mathrm{n} \quad \text { peraturan } \\
\text { organisasi }\end{array}$} & \multirow{3}{*}{\multicolumn{2}{|c|}{$\begin{array}{l}\text { Media yang Rapat } \\
\text { dipilih }\end{array}$}} & Umpan balik \\
\hline & & & Bersama-sama dan cepat \\
\hline & & & Interaksi antar karyawan \\
\hline & \multirow{7}{*}{$\begin{array}{l}\text { Media } \\
\text { tidak } \\
\text { dipilih }\end{array}$} & Kontak & Singkat dan mudah \\
\hline & & interpersonal & $\begin{array}{l}\text { Tidak memerlukan catatan } \\
\text { permanen }\end{array}$ \\
\hline & & Laporan lisan & Umpan balik \\
\hline & & Wawancara & Singkat dan mudah \\
\hline & & & $\begin{array}{l}\text { Tidak memerlukan catatan } \\
\text { permanen }\end{array}$ \\
\hline & & $\begin{array}{l}\text { Kontak } \\
\text { interpersonal }\end{array}$ & Secara bersama-sama dan cepat \\
\hline & & Telepon & Interaksi antar karyawan \\
\hline \multirow{10}{*}{$\begin{array}{l}\text { Menginformasika } \\
\mathrm{n} \text { data dan } \\
\text { kebiasaan } \\
\text { organisasi }\end{array}$} & \multirow{4}{*}{$\begin{array}{l}\text { Media yang } \\
\text { dipilih }\end{array}$} & Rapat & Umpan balik \\
\hline & & $x^{2}$ & Bersama-sama dan cepat \\
\hline & & & Interaksi antar karyawan \\
\hline & & Kontak & Singkat dan mudah \\
\hline & \multirow{6}{*}{$\begin{array}{l}\text { Media } \\
\text { tidak } \\
\text { dipilih }\end{array}$} & interpersonal & $\begin{array}{l}\text { Tidak memerlukan catatan } \\
\text { permanen }\end{array}$ \\
\hline & & Laporan lisan & Umpan balik \\
\hline & & Wawancara & Singkat dan mudah \\
\hline & & & $\begin{array}{l}\text { Tidak memerlukan catatan } \\
\text { permanen }\end{array}$ \\
\hline & & $\begin{array}{l}\text { Kontak } \\
\text { interpersonal }\end{array}$ & Secara bersama-sama dan cepat \\
\hline & & Telepon & Interaksi antar karyawan \\
\hline
\end{tabular}

Sumber: Data Primer, Panduan Pertanyaan 
Hasil di atas menunjukkan bahwa media komunikasi yang paling digunakan oleh atasan dalam pelaksanaan downward communication untuk tujuan informasi adalah:

a. Rapat, karena pada saat rapat dapat diperoleh umpan balik secara langsung dari bawahan; dapat menjangkau banyak karyawan dan dilakukan dengan cepat; dan dapat mendorong interaksi antar karyawan sehingga dapat membantu memecahkan masalah.

b. Kontak interpersonal, dengan faktor pendorong singkat dan mudah, serta tidak memerlukan catatan permanen.

Sementara itu, media yang paling tidak disarankan adalah:

a. Laporan lisan, dengan alasan tidak ada kesempatan untuk umpan balik secara bebas.

b. Wawancara dengan alasan tidak singkat dan mudah dan bukan berarti tidak memerlukan catatan permanen.

c. Kontak interpersonal, dengan alasan bahwa media ini tidak dapat menjangkau sejumlah karyawan yang dimaksud sehingga tidak dapat memberikan pesan informasi secara bersama-sama dengan cepat.

d. Telepon dengan alasan tidak dapat mendorong interaksi antar karyawan sehingga karyawan dapat memecahkan permasalahan secara bersama-sama.

Dari hasil temuan penelitian di atas menunjukkan bahwa media komunikasi pada downward communication yang paling dipilih karyawan dalam rangka tujuan pesan informasi adalah rapat dan kontak interpersonal. Alasan yang dikemukakan adalah bahwa melalui rapat maka akan dapat memperoleh umpan balik secara langsung dari bawahan; dapat menjangkau banyak karyawan dan dilakukan dengan cepat; dan dapat mendorong interaksi antar karyawan sehingga dapat membantu memecahkan masalah. Dari data di lapangan ditemukan bahwa media rapat biasanya digunakan pada saat memberikan informasi tentang peraturan dan data-data serta kebiasaan organisasi untuk mengurangi salah paham yang sering terjadi antar karyawan karena ketidaktahuan mereka terhadap peraturan organisasi, profil perusahaan, data-data produk di brosur penjualan juga mengenai ketentuan-ketentuan sesuai jobdescription.

Selain rapat media yang paling digunakan oleh karyawan untuk menyampaikan pesan informasi adalah kontak interpersonal karena media lisan ini singkat dan mudah dalam penyampaiannya dan tidak memerlukan catatan permanen. Hal ini juga dikarenakan oleh sifat dari kontak interpersonal itu sendiri yaitu pesannya dua arah (two ways communication) (Ruslan, 2002, p.204) dan merupakan alat komunikasi yang paling efektif dan diinginkan oleh karyawan (Tucker, Derelian \& Rouner, 1997, p.237).

Sementara penggunaan kontak personal untuk menyampaikan pesan informasi yang biasanya agar pesan informasi ini dapat diterima dengan mudah karena timbul keakraban yang terjalin dari hubungan yang baik antara atasan dan bawahan dan adanya pengertian dari kedua belah pihak untuk saling mentaati peraturan, agar pembicaraan yang terjadi jauh dari sisi keformalitasan sehingga tidak membutuhkan catatan permanen sebagai bukti dan tanpa persiapan terlebih dahulu serta bisa dilakukan kapan saja ketika informasi itu harus dibicarakan. 
Meskipun demikian, kontak interpersonal juga bukan merupakan media yang digunakan untuk menyampaikan pesan informasi karena media ini tidak dapat menjangkau sejumlah karyawan yang dimaksud sehingga tidak dapat menyampaikan pesan informasi secara bersama-sama dan cepat. Hal ini karena karakteristik kontak interpersonal adalah one to one communication sehingga kurang tepat digunakan untuk atasan mengkomunikasikan pesan informasi secara bersama-sama dan cepat. Sehingga yang ada pada saat terjadi kontak interpersonal adalah seorang atasan dan seorang bawahan sehingga tidak memungkinkan terjadinya hubungan dengan karyawan lainnya pada saat itu dan berusaha memecahkan permasalahan bersama-sama. Kecuali apabila, karyawan yang dipanggil dalam jumlah lebih dari satu.

Laporan lisan juga bukan merupakan media yang paling digunakan oleh karyawan dalam penyampaian pesan informasi oleh karena faktor-faktor yaitu, tidak dapat memberikan umpan balik secara langsung. Formalitas ini cenderung memperbesar jarak antara atasan dengan bawahan, di mana pada akhirnya bawahan akan hanya berperan sebagai pendengar merasa kesulitan untuk mengakrabkan diri. Apalagi di dalam laporan lisan, seorang penyampai laporan harus mampu mengendalikan jumlah interaksi antara pembicara dan pendengar yaitu mengendalikan apa yang sebenarnya terjadi selama pembicaraan atau presentasi (Bovee \& Thill, 2002, p. 628). Sebagaimana diutarakan oleh salah seorang responden bahwa peluang untuk menyampaikan umpan balik pada media laporan lisan cukup terbatas karena waktu yang tersedia lebih banyak digunakan oleh atasan atau pihak yang ditunjuk untuk menyampaikan laporan tersebut.

Sedangkan wawancara tidak digunakan oleh atasan untuk menyampaikan pesan informasi karena faktor-faktor tidak singkat dan mudah juga bukan berarti tidak membutuhkan catatan permanen. Hasil ini menunjukkan bahwa meskipun melalui wawancara terjadi pembicaraan yang lebih formal daripada percakapan sehingga wawancara memiliki ciri derajat perintah yang lebih tinggi, keakuratan lebih tajam dan penyimpangan pembicaraan yang lebih sedikit akan tetapi pendekatan ini kurang luwes, mengurangi semangat kerjasama dan membatasi pilihan jawaban bagi orang yang diwawancarai karena pada awal interaksi pewawancara menetapkan tujuan-tujuan situasi (Curtis et.al., 2004, p.86). Berdasarkan hasil diskusi diperoleh data bahwa wawancara cenderung formal sehingga bawahan kurang memiliki kesempatan untuk mengungkapkan pertanyaan-pertanyaan atau pernyataan dengan bebas.

Sementara itu, media telepon juga bukan merupakan media yang paling disarankan apabila tujuan informasi tersebut adalah untuk mendorong interaksi antar karyawan sehingga karyawan dapat memecahkan permasalahan secara bersama-sama. Hal ini karena meskipun penggunaan media komunikasi di perkantoran memiliki dampak positif seperti, meningkatkan efisiensi dan produktivitas, mempermudah pengiriman dan penerimaan informasi, mengurangi kekakuan struktur birokrasi, dan memungkinkan terjadinya desentralisasi pengambilan keputusan; akan tetapi penggunaan media juga memiliki dampak negatif yaitu para anggota perkantoran kehilangan kesempatan untuk saling berkomunikasi secara interpersonal (Suranto, 2005, p.130-131). 
Tabel 5. Media Komunikasi Lisan Downward Communication untuk Tujuan Balikan yang Dipilih dan Tidak Dipilih Karyawan

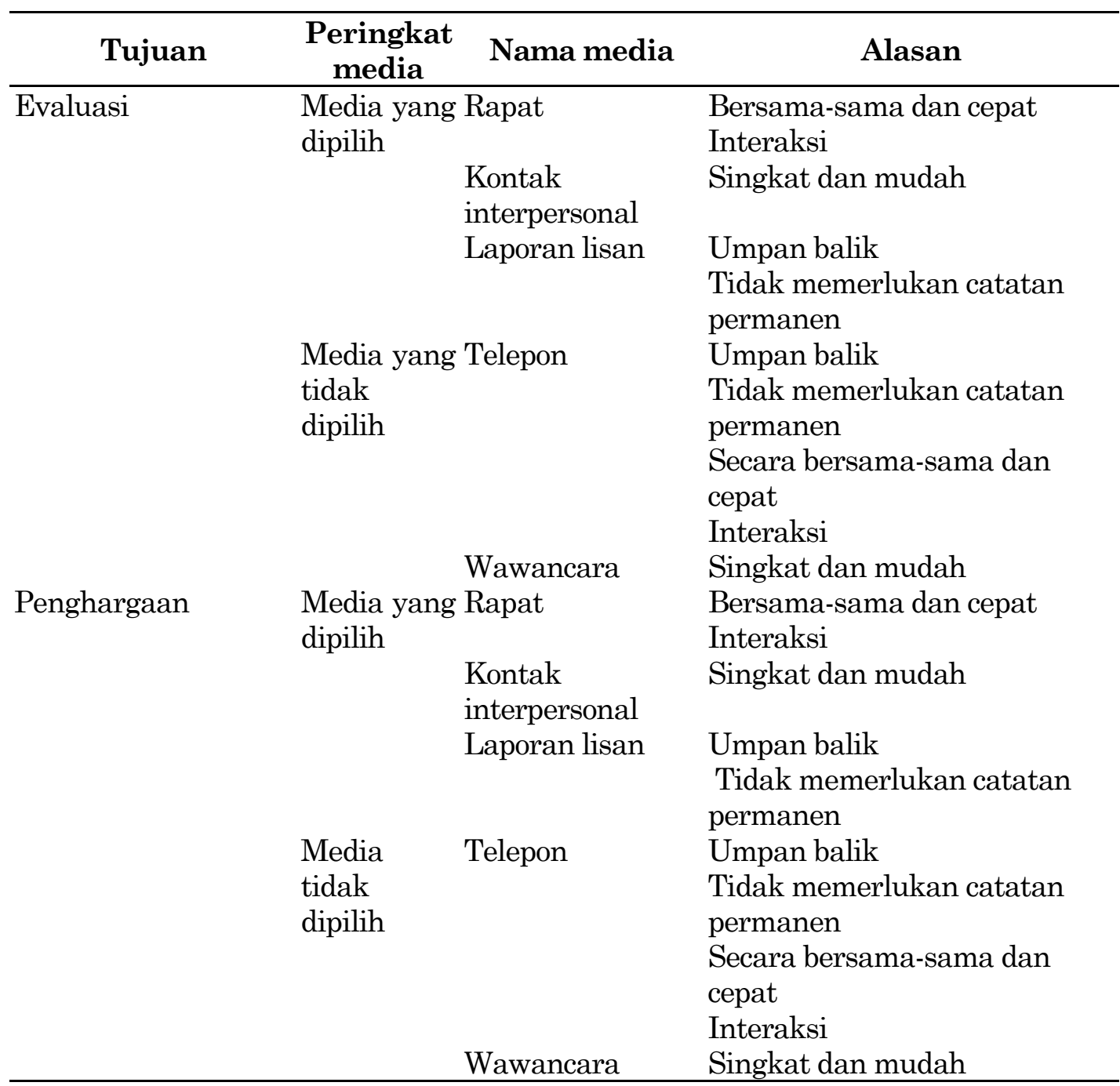

Sumber : Data Primer, Panduan Pertanyaan

Hasil di atas menunjukkan bahwa media yang paling digunakan oleh atasan dalam pelaksanaan komunikasi downward untuk tujuan balikan adalah:

a. Rapat karena dapat menjangkau banyak karyawan dan cepat serta dapat mendorong interaksi antar karyawan sehingga dapat membantu memecahkan masalah.

b. Kontak interpersonal dengan faktor pendorongnya adalah singkat dan mudah

c. Laporan lisan dengan faktor pendorongnya adalah dapat memperoleh umpan balik secara langsung dari bawahan dan tidak memerlukan catatan permanen

Sementara itu media yang paling tidak digunakan adalah:

a. Telepon dengan alasan atasan tidak dapat menilai umpan balik secara langsung, bukan berarti tidak memerlukan catatan permanen, tidak dapat memberikan pesan balikan secara bersama-sama dan cepat, tidak dapat mendorong interaksi 
antar karyawan sehingga karyawan dapat memecahkan permasalahan bersamasama.

b. Wawancara dengan alasan media ini tidak singkat dan mudah.

Hasil penelitian di atas menunjukkan bahwa media komunikasi pada downward communication secara lisan yang paling dipilih karyawan dalam rangka untuk mendapatkan pesan balikan adalah rapat, kontak interpersonal dan laporan lisan. Dengan alasan melalui rapat maka akan dapat menjangkau banyak karyawan dan cepat serta dapat mendorong interaksi antar karyawan sehingga dapat membantu memecahkan permasalahan yang dihadapi. Media rapat biasanya digunakan pada saat akan melakukan tindakan evaluasi sehingga menjadi lebih cepat dan dapat diterima langsung oleh seluruh karyawan. Karyawan dapat dijelaskan mengenai kesalahan yang telah dilakukan sehingga dapat diperbaiki untuk pekerjaan yang akan datang dan jika atasan menginginkan pembicaraan yang lebih intens biasanya atasan lebih memilih media laporan lisan.

Selain rapat, media yang dipilih karyawan dalam penyampaian pesan balikan adalah kontak interpersonal karena sifat dari media lisan ini sendiri pesannya dua arah (two ways communication) dan merupakan alat komunikasi yang paling efektif dan diinginkan oleh karyawan (Tucker, Derelian \& Rouner, 1997, p.237) sehingga singkat dan mudah dalam penyampaiannya.

Pesan balikan yang disampaikan melalui kontak interpersonal biasanya bertujuan untuk evaluasi kerja karyawan yang dapat diberikan dengan cara singkat dan diterima dengan mudah, serta penghargaan atas prestasi karyawan dapat diberikan dengan cara singkat dan diterima dengan mudah.

Selanjutnya, laporan lisan juga merupakan media yang paling dipilih karyawan dalam penyampaian pesan balikan karena melalui laporan lisan dapat memberikan umpan balik secara langsung dan tidak memerlukan catatan permanen. Hal ini menunjukkan bahwa melalui laporan lisan maka atasan dapat memberikan evaluasi dan penghargaan kepada karyawan dengan umpan balik langsung yang didapat dari karyawan sehingga tidak membutuhkan catatan permanen. Media yang tidak dipilih apabila tujuan aliran pesan adalah informasi balikan, diantaranya adalah telepon. Hal ini dikarenakan, meskipun telepon adalah media yang efektif karena masih ada kesempatan untuk mendapatkan umpan balik langsung, klarifikasi dan tindakan dari orang yang kita ajak bicara (Walsh, 1986, p.168), akan tetapi, pembicaraan melalui telepon memerlukan sedikit dorongan dan penjelasan dan perlu adanya pendekatan yang akrab dan ramah demi menghilangkan jurang artifisial antara pihak manajemen dengan segenap pegawai (Jefkins, 1992, p.175).

Oleh karena itu, jika atasan berkeinginan untuk memberikan evaluasi berupa masukan atas tugas yang telah dilakukan karyawan maka atasan memerlukan sarana lain atau memerlukan penekanan lain pada saat melakukan komunikasi melalui telepon karena umpan balik yang disampaikan oleh karyawan tidak mungkin dapat dinilai secara langsung oleh atasan. Umpan balik menurut Thoha (2005) juga berarti suatu proses laporan tentang apa yang dikatakan oleh pengirim, dapat atau tidak membentuk pengertian pada penerima (p.179). Apalagi, suatu umpan balik bisa dikatakan efektif apabila dapat dimengerti secara jelas oleh penerima dengan cara melihat ekspresi raut muka sebagai salah satu indikator adanya pengertian (Thoha, 2005, p.183). Hal ini tentu saja tidak dapat dilakukan melalui media telepon yang hanya berdasarkan suara sehingga umpan balik yang diterima 
kurang efektif. Sebagaimana dikatakan oleh salah seorang responden bahwa penggunaan telepon memang efektif, tetapi perlu juga melihat konteks penggunaan atau tujuan penggunaan. Jika atasan berkeinginan untuk menyampaikan evaluasi berupa masukan atas tugas yang telah dilakukan karyawan maka diperlukan suatu pendekatan yang lebih besar dibandingkan dengan telepon. Apalagi di dalam melakukan laporan lisan diperlukan interaksi langsung antara atasan dan bawahan sehingga dapat dimengerti oleh keduanya, sehingga laporan lisan kurang tepat apabila menggunakan media telepon.

Sedangkan wawancara juga tidak dipilih karyawan untuk menerima pesan balikan karena faktor tidak singkat dan mudah. Hasil ini menunjukkan bahwa meskipun melalui wawancara terjadi pembicaraan yang lebih formal daripada percakapan sehingga wawancara memiliki ciri derajat perintah yang lebih tinggi, keakuratan yang lebih tajam dan penyimpangan pembicaraan yang lebih sedikit, akan tetapi pendekatan ini kurang luwes, mengurangi semangat kerjasama dan membatasi pilihan jawaban bagi orang yang diwawancarai karena pada awal interaksi pewawancara menetapkan tujuan-tujuan situasi (Curtis et. al., 2004, p.86), sehingga kurang tepat digunakan untuk menyampaikan evaluasi kepada karyawan apabila dengan tujuan evaluasi itu dapat disampaikan secara singkat dan mudah diterima oleh karyawan. Berdasarkan temuan penelitian, diketahui bahwa wawancara cenderung formal sehingga bawahan kurang memiliki kebebasan untuk menyampaikan pernyataan dan pertanyaan-pertanyaan yang menyangkut evaluasi karyawan. Hal ini dapat dijelaskan bahwa wawancara memiliki karakteristik lebih formal dibandingkan dengan percakapan biasa sehingga karyawan memiliki kerikuhan untuk memberikan umpan balik secara langsung secara bebas karena pada tipe media ini, pewawancara cenderung memiliki otoritas lebih tinggi dan berperan sebagai penentu arah pembicaraan.

Tabel 6. Media Komunikasi Tulisan pada Downward Communicatio untuk Tujuan Instruksi Tugas yang Dipilih dan Tidak Dipilih Karyawan

\begin{tabular}{|c|c|c|c|}
\hline Tujuan & $\begin{array}{l}\text { Peringkat } \\
\text { media }\end{array}$ & Nama media & Alasan \\
\hline \multirow[t]{8}{*}{$\begin{array}{l}\text { Mendelegasikan } \\
\text { tugas }\end{array}$} & \multirow{5}{*}{$\begin{array}{l}\text { Media } \\
\text { paling } \\
\text { digunakan }\end{array}$} & \multirow[t]{2}{*}{ Memo } & $\begin{array}{l}\text { Tidak memerlukan umpan } \\
\text { balik }\end{array}$ \\
\hline & & & $\begin{array}{l}\text { Memerlukan catatan yang } \\
\text { dapat dijadikan sebagai bukti }\end{array}$ \\
\hline & & Laporan bulanan & $\begin{array}{l}\text { Rinci, sifatnya kompleks dan } \\
\text { memerlukan perencanaan } \\
\text { yang seksama }\end{array}$ \\
\hline & & Job description & $\begin{array}{l}\text { Disampaikan dalam jumlah } \\
\text { karyawan yang banyak dan } \\
\text { berada di beberapa lokasi }\end{array}$ \\
\hline & & \multirow{4}{*}{$\begin{array}{l}\text { Pedoman } \\
\text { kebijaksanaan } \\
\text { Pedoman } \\
\text { kebijaksanaan }\end{array}$} & $\begin{array}{l}\text { Akurat tanpa terjadi } \\
\text { penyimpangan pesan }\end{array}$ \\
\hline & Media & & Tidak memerlukan umpan \\
\hline & paling & & balik \\
\hline & $\begin{array}{l}\text { tidak } \\
\text { diounakan }\end{array}$ & & $\begin{array}{l}\text { Memerlukan catatan yang } \\
\text { danat dijadikan sebagai bukti }\end{array}$ \\
\hline
\end{tabular}




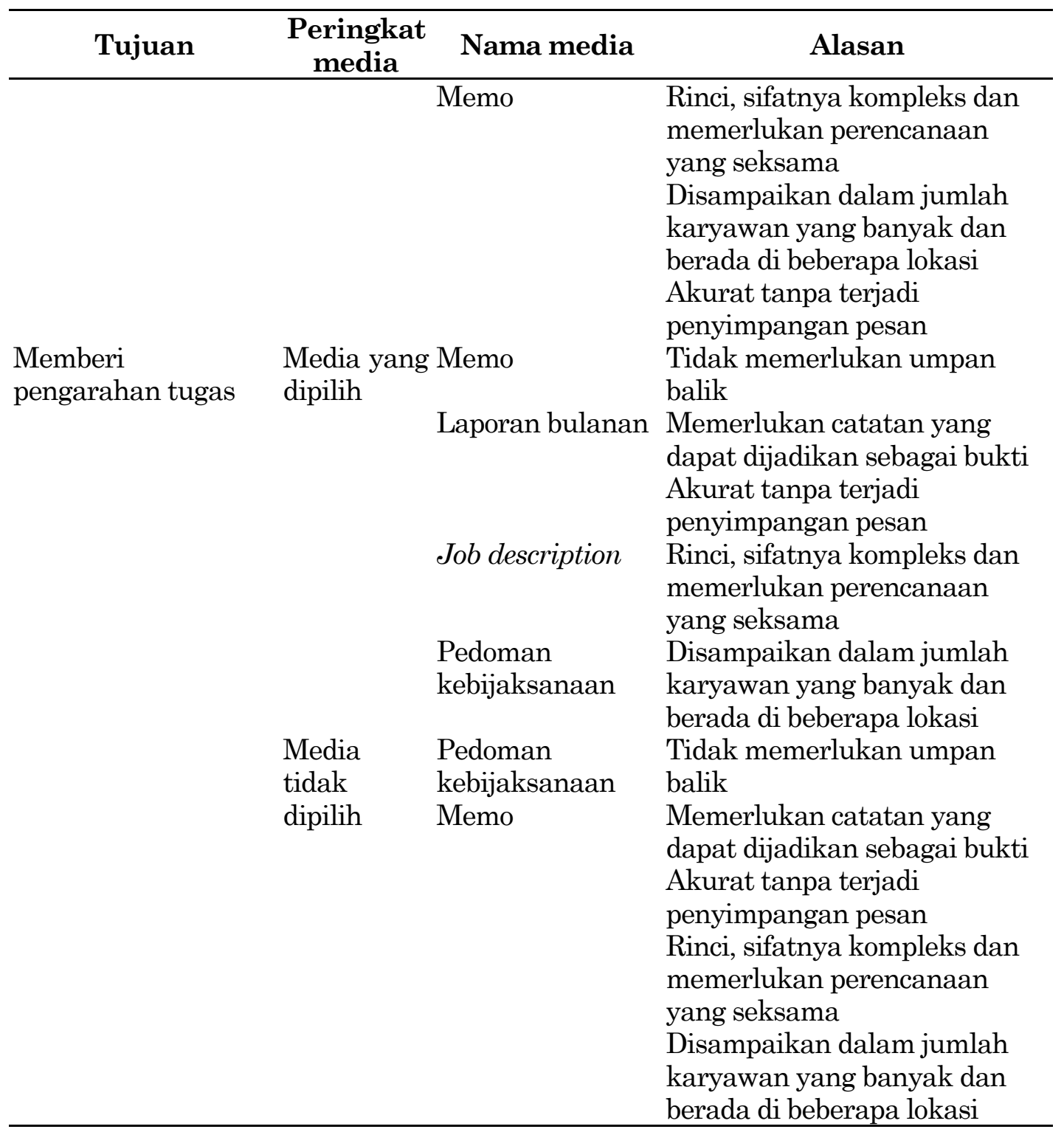

Sumber: Data Primer, Panduan Pertanyaan

Hasil di atas menunjukkan bahwa media komunikasi tulisan yang dipilih karyawan dalam downward communication untuk tujuan instruksi tugas adalah:

a. Memo, dengan alasan memo tidak memerlukan umpan balik dan memerlukan catatan yang dapat dijadikan sebagai bukti.

b. Laporan bulanan, dengan alasan instruksi tugas tersebut dapat disampaikan dengan rinci, sifatnya kompleks, memerlukan perencanaan yang seksama, karena atasan memerlukan catatan yang dapat dijadikan sebagai bukti, dan sifatnya yang akurat tanpa terjadi penyimpangan pesan.

c. Job description, karena dapat disampaikan pada karyawan dalam jumlah banyak dan berada di beberapa lokasi, sifatnya rinci, kompleks, dan memerlukan perencanaan. 
d. Pedoman kebijaksanaaan, karena dapat disampaikan pada karyawan dalam jumlah banyak, berada di beberapa lokasi, dan sifatnya yang akurat tanpa terjadi penyimpangan pesan.

Sementara media yang paling tidak dipilih adalah:

a. Pedoman kebijaksanaan, dengan alasan karena atasan tidak memerlukan umpan balik dan catatan yang dapat dijadikan sebagai bukti.

b. Memo, dengan alasan bahwa media ini tidak dapat menjangkau sejumlah karyawan sekaligus sehingga tidak dapat memberikan pesan instruksi tugas dengan cepat; kurang akurat sehingga tidak dapat meminimalkan kesalahan penyampaian pesan; serta sifatnya yang tidak terinci rinci, tidak kompleks dan tidak memerlukan perencanaan yang seksama. Alasan lainnya adalah juga bahwa media ini tidak dapat digunakan untuk menyampaikan pengarahan tugas jika atasan memerlukan catatan permanen sebagai bukti.

Alasan yang dikemukakan berkaitan dengan pengggunaan memo di atas sesuai dengan karakteristik memo yang merupakan dokumen yang relatif pendek, pada umumnya satu atau dua halaman dan digunakan untuk pertukaran informasi rutin sehari-hari dalam sebuah organsasi (Bovée \& Thill, 2003, p.122). Di mana menurut O'Rourke (2001) bahwa tujuan penyampaian memo adalah untuk menimbulkan tiga tindakan dari pembacanya yaitu meminta bantuan, memberi petunjuk, dan mencari persetujuan dari pembacanya (p.86). Dengan demikian, memo bukan bertujuan untuk mendapatkan umpan balik dengan segera pada saat disampaikannya memo, tetapi penyampaian memo bertujuan agar pembaca memo melakukan tindakan sebagaimana yang diinginkan oleh penulis memo.

Sementara itu berkaitan dengan penggunaan laporan bulanan yang banyak dipilih karena rinci, sifatnya kompleks, memerlukan perencanaan yang seksama, karena atasan memerlukan catatan yang dapat dijadikan sebagai bukti, dan sifatnya yang akurat tanpa terjadi penyimpangan pesan, Bovee dan Thill (2003) mendukung alasan ini karena laporan tertulis pada umumnya lebih panjang dan lebih formal dibandingkan surat dan memo, serta merupakan dokumen faktual dan objektif yang mungkin didistribusikan kepada orang dalam atau luar, tergantung pada tujuan dan subjeknya (p. 124).

Data temuan penelitian lebih lanjut menunjukkkan bahwa laporan bulanan digunakan untuk penyampaian laporan berikut hasil evaluasinya, di mana hasil evaluasi tersebut digunakan sebagai landasan untuk menyampaikan rincian tugas yang harus dilakukan oleh karyawan, dan laporan bulanan digunakan sebagai dokumen formal yang harus diarsipkan sebagai bahan penyusunan laporan kwartal dan tahunan.

Di samping memo dan laporan bulanan, job decription juga sangat disarankan untuk digunakan oleh atasan dengan alasan akurasi penyampaian pesan dan penyampaian pesan lebih rinci, serta dapat menjangkau karyawan dalam jumlah yang banyak. Media komunikasi lainnya yang dipilih karyawan adalah pedoman kebijaksanaan dengan alasan akurasi dan dapat menjangkau karyawan dalam jumlah banyak. Hal ini karena pedoman kebijaksanaan merupakan suatu naskah tertulis yang berisi keterangan tentang berbagai keputusan pimpinan mengenai berbagai masalah yang belum ada peraturan yang timbul pada saat organisasi sedang menjalankan kegiatannya. Di mana kebijakan tertulis ini dapat dibaca dan 
dibaca ulang oleh siapa pun yang perlu mengetahui isu tertentu (Bovée \& Thill, 2002, p. 484).

Meskipun demikian, jika penyampaian instruksi tugas tersebut dengan alasan tidak memerlukan umpan balik secara langsung maka pedoman kebijaksanaan bukanlah media yang paling dipilih karyawan. Sebagaimana menurut Bovée \& Thill (2002), pedoman kebijaksanaan merupakan sebuah laporan yang mengimplementasikan kebijakan dan prosedur mempunyai pengaturan yang lugas, tetapi mungkin sulit untuk ditulis dengan baik sehingga pendekatan ini lebih sering menciptakan kebingungan daripada memberikan penjelasan. Apalagi bentuknya merupakan suatu naskah tertulis yang berisi keterangan tentang berbagai keputusan pimpinan mengenai berbagai masalah yang belum ada peraturan yang timbul pada saat organisasi sedang menjalankan kegiatannya. (p.484). Hasil pengamatan dan wawancara menunjukkan bahwa pedoman kebijaksanaan digunakan untuk menyampaikan prosedur dan peraturan organisasi yang sifatnya lebih luas, misalnya, tata cara pelayanan pelanggan, tata cara penggunaan sarana dan prasarana, tujuan pelaksanaan suatu prosedur secara tepat dan lain-lain. Sementara kalalu untuk menyampaikan perintah kepada bawahan, penggunaan pedoman kebijaksanaan merupakan hal yang tidak pada tempatnya karena semua sudah ada penggunaannya masing-masing.

Tabel 7. Media Komunikasi Tulisan pada Downward Communication untuk Tujuan Rasional yang Dipilih dan Tidak Dipilih Karyawan

\begin{tabular}{|c|c|c|c|}
\hline Tujuan & $\begin{array}{c}\text { Peringkat } \\
\text { media }\end{array}$ & Nama media & Alasan \\
\hline \multirow[t]{6}{*}{$\begin{array}{l}\text { Menyampaikan } \\
\text { informasi tujuan } \\
\text { pelaksanaan tugas }\end{array}$} & $\begin{array}{l}\text { Media } \\
\text { dipilih }\end{array}$ & $\begin{array}{l}\text { Pedoman } \\
\text { kebijaksanaan }\end{array}$ & $\begin{array}{l}\text { Tidak memerlukan umpan balik } \\
\text { Memerlukan catatan yang dapat } \\
\text { dijadikan sebagai bukti } \\
\text { Rinci, sifatnya kompleks dan } \\
\text { memerlukan perencanaan yang } \\
\text { seksama }\end{array}$ \\
\hline & & Laporan bulanan & $\begin{array}{l}\text { Disampaikan dalam jumlah } \\
\text { karyawan yang banyak dan } \\
\text { berada di beberapa lokasi } \\
\text { Akurat tanpa terjadi } \\
\text { penyimpangan pesan }\end{array}$ \\
\hline & $\begin{array}{l}\text { Media } \\
\text { tidak } \\
\text { dipilih }\end{array}$ & Memo & $\begin{array}{l}\text { Tidak memerlukan umpan balik } \\
\text { Memerlukan catatan yang dapat } \\
\text { dijadikan sebagai bukti Rinci, } \\
\text { sifatnya kompleks dan } \\
\text { memerlukan perencanaan yang } \\
\text { seksama }\end{array}$ \\
\hline & & & Disampaikan dalam jumlah \\
\hline & & & $\begin{array}{l}\text { karyawan yang banyak dan } \\
\text { berada di beberapa lokasi }\end{array}$ \\
\hline & & & $\begin{array}{l}\text { Akurat tanpa terjadi } \\
\text { penyimpangan pesan }\end{array}$ \\
\hline
\end{tabular}




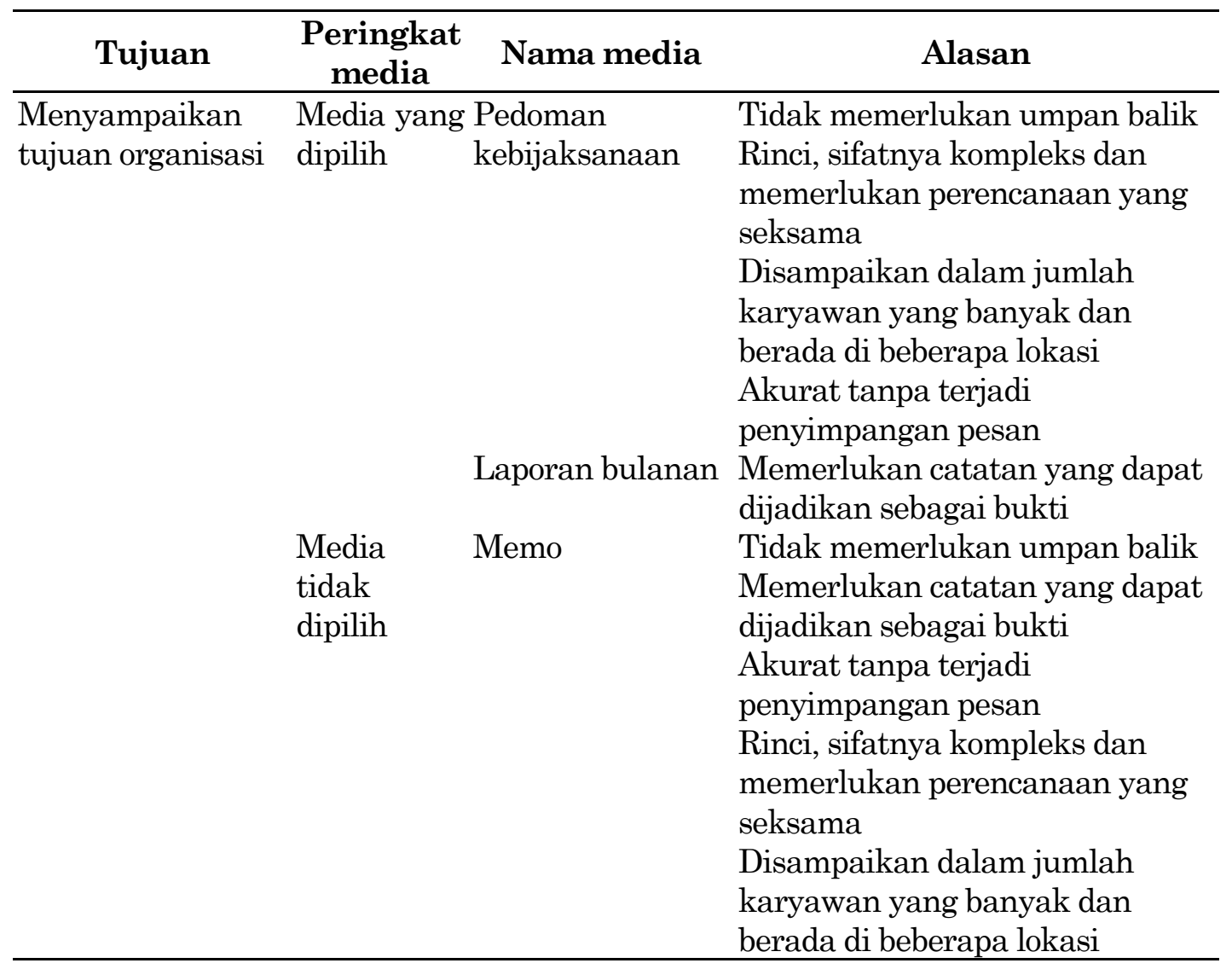

Sumber: Data Primer, Panduan Pertanyaan

Hasil di atas menunjukkan bahwa media yang paling dipilih karyawan dalam aliran pesan dari atasan ke bawahan untuk tujuan rasional tugas adalah:

I. Penyampaian informasi untuk tujuan pelaksanaan tugas;

a. Pedoman kebijaksanaan karena tidak memerlukan umpan balik; memerlukan catatan yang dapat dijadikan sebagai bukti; rinci, sifatnya kompleks dan memerlukan perencanaan yang seksama.

b. Laporan bulanan karena dapat disampaikan langsung pada karyawan dalam jumlah banyak dan tersebar di beberapa lokasi sekaligus; sifatnya akurat sehingga meminimalkan terjadinya kesalahan informasi.

II. Penyampaian tujuan organisasi adalah:

a. Pedoman kebijaksanaan karena tidak memerlukan umpan balik; rinci, sifatnya kompleks dan memerlukan perencanaan yang seksama; disampaikan dalam jumlah karyawan yang banyak dan tersebar di beberapa lokasi sekaligus; sifatnya akurat sehingga meminimalkan terjadinya kesalahan informasi.

b. Laporan bulanan karena memerlukan catatan yang dapat dijadikan sebagai bukti.

Sementara itu media yang tidak dipilih adalah memo dengan alasan karena tidak memerlukan umpan balik; memerlukan catatan yang dapat dijadikan sebagai bukti; rinci, sifatnya kompleks dan memerlukan perencanaan yang seksama; dapat 
disampaikan dalam jumlah karyawan yang banyak dan tersebar di beberapa lokasi sekaligus; sifatnya akurat sehingga meminimalkan terjadinya kesalahan informasi.

Alasan dipilihnya pedoman kebijaksanaan untuk tujuan rasional sesuai dengan karakteristik pedoman kebijaksanaan menurut Bovée \& Thill (2002) yang mengungkapkan bahwa pedoman kebijaksanaan merupakan sebuah laporan yang mengimplementasikan kebijakan dan prosedur, mempunyai pengaturan yang lugas, tetapi mungkin sulit untuk ditulis dengan baik sehingga pendekatan ini lebih sering menciptakan kebingungan daripada memberikan penjelasan. Apalagi bentuknya merupakan suatu naskah tertulis yang berisi keterangan tentang berbagai keputusan pimpinan mengenai berbagai masalah yang belum ada peraturan yang timbul pada saat organisasi sedang menjalankan kegiatannya (p.484).

Atasan perlu berkomunikasi dengan karyawan, tetapi biasanya mereka tidak dapat berbicara langsung dengan setiap orang dalam organisasi. Kebijakan tertulis dapat dibaca dan dibaca ulang oleh siapa pun yang perlu mengetahui isu tertentu (Bovée \& Thill, 2002, p. 484) sehingga tidak membutuhkan umpan balik langsung. Selain itu pedoman kebijaksanaan dapat membantu manajer mengkomunikasikan standar perusahaan, membantu mengimplementasikan kebijakan dan prosedur, memonitor dan mengendalikan operasi (Bovée \& Thill, 2002, p. 476).

Hasil diskusi juga menunjukkkan bahwa laporan bulanan digunakan dalam hal penyampaian laporan berikut hasil evaluasinya, di mana hasil evaluasi tersebut digunakan sebagai landasan untuk menyampaikan rincian tugas yang harus dilakukan karyawan, laporan bulanan juga digunakan sebagai dokumen formal yang harus diarsipkan sebagai bahan penyusunan laporan kwartal dan tahunan sehingga laporan bulanan juga merupakan media yang dipilih karyawan.

Sementara itu, media yang tidak dipilih adalah memo dengan alasan karena masih memerlukan umpan balik; tidak dapat dijadikan catatan permanen sebagai bukti; tidak rinci, tidak kompleks dan tidak memerlukan perencanaan yang seksama; tidak dapat disampaikan dalam jumlah karyawan yang banyak dan tersebar di beberapa lokasi; kurang akurat sehingga dapat menimbulkan terjadinya kesalahan informasi. Selain itu media tulisan memo tidak dipilih karena karakteristik memo yang cukup sederhana sehingga ditekankan digunakan pada pembaca yang kemungkinan hanya mempunyai waktu terbatas untuk membaca sepintas pesan tersebut (Bovée \& Thill, 2003, p.122). Padahal, di dalam penyampaian pesan rasional diperlukan penjelasan sesuai dengan kebutuhan dengan mempertimbangkan kualitas dan posisi karyawan. Bila atasan menganggap bawahannya pemalas, atau hanya mau bekerja bila dipaksa, maka pimpinan hanya akan sedikit memberikan pesan yanng bersifat rasional ini. Tetapi apabila pimpinan menganggap bawahannya orang yang dapat memotivasi diri sendiri dan produktif, maka biasanya diberikan pesan rasional yang banyak (Muhammad, 2005, p.108-110). Dalam kenyataannya, memo kebanyakan hanya digunakan untuk menyampaikan pesan pelaksanaan tugas rutin sehari-hari yang ditulis dengan singkat. 
Tabel 8. Media Komunikasi Tulisan Downward Tulisan untuk Tujuan Ideologi yang Dipilih dan Tidak Dipilih Karyawan

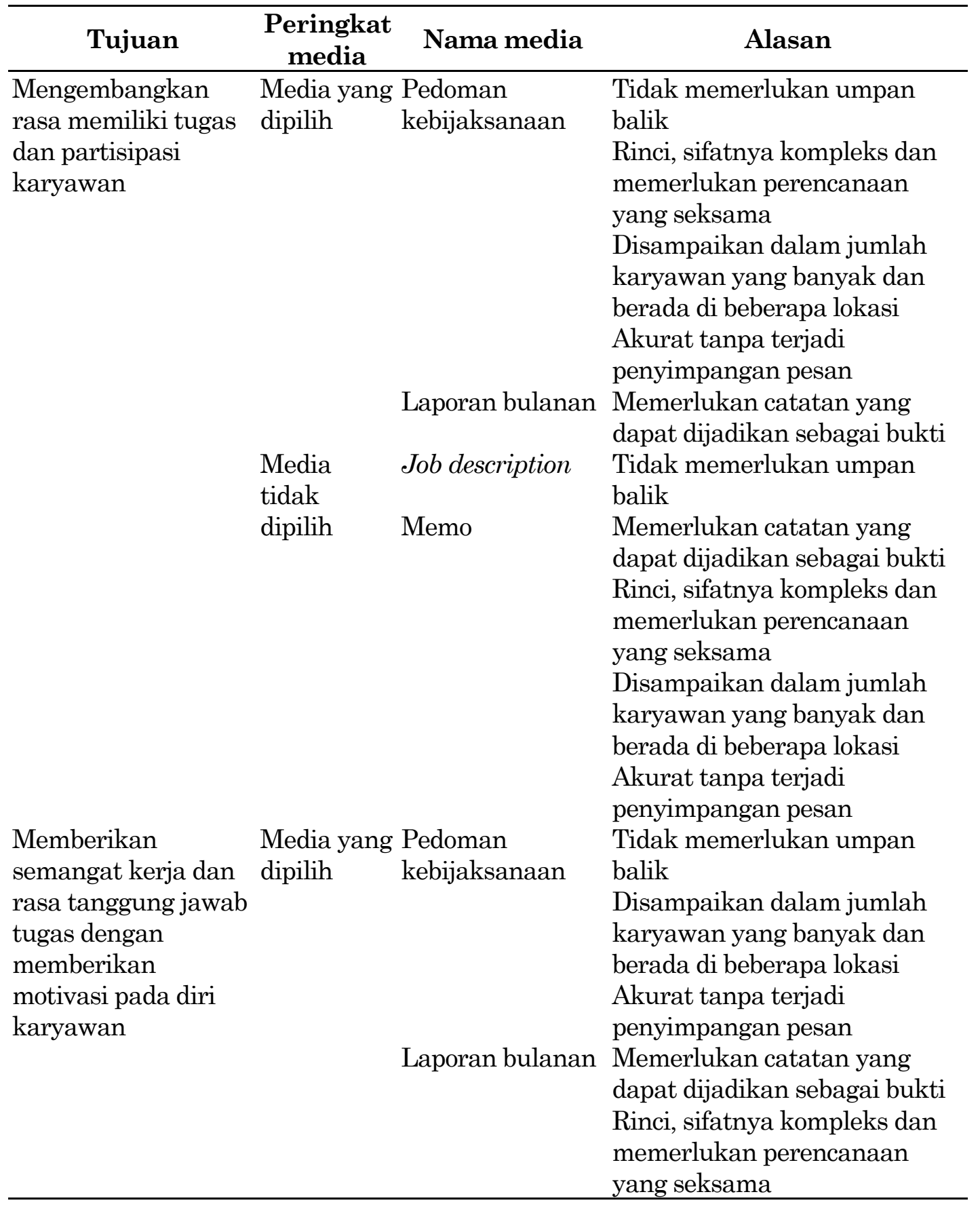




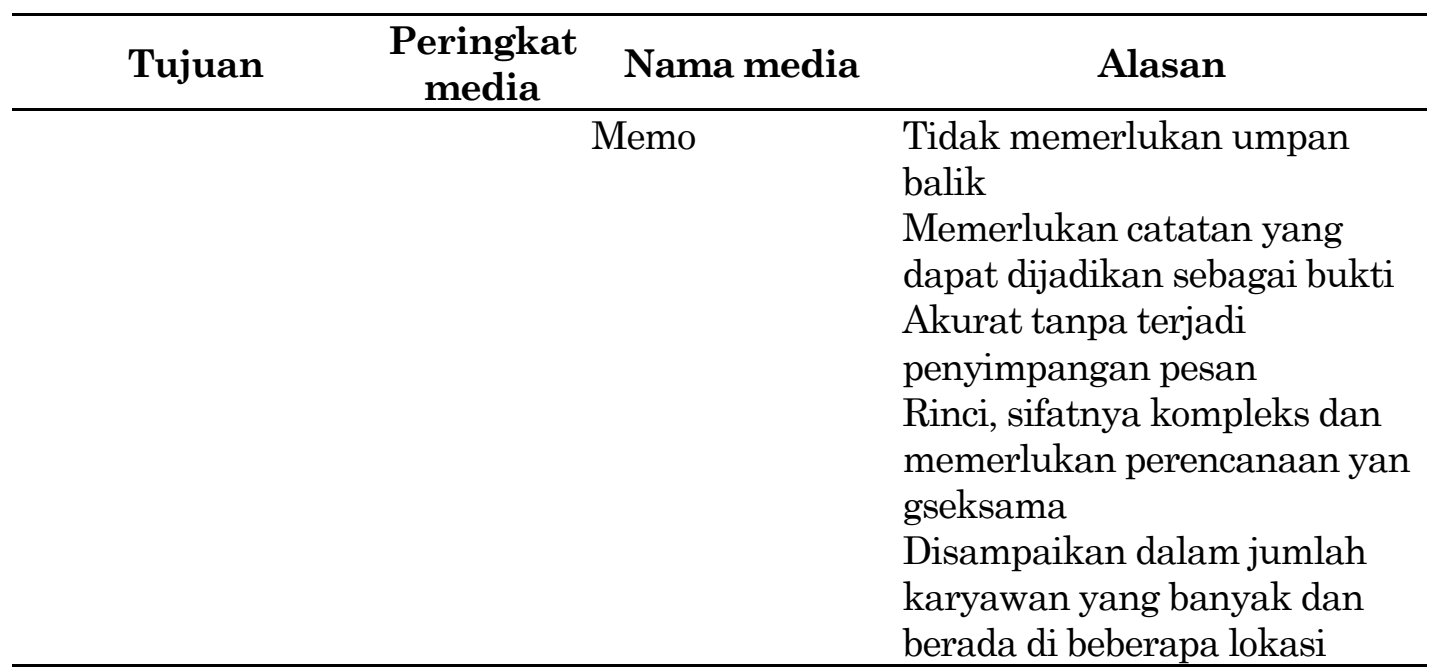

Sumber: Data Primer, Panduan Pertanyaan

Hasil di atas menunjukkan bahwa media yang paling dipilih oleh karyawan dalam pelaksanaan komunikasi downward untuk tujuan mengembangkan tugas dan partisipasi karyawan adalah:

a. Pedoman kebijaksanaan, karena tidak memerlukan umpan balik; dapat dilakukan rinci, sifatnya kompleks dan memerlukan perencanaan yang seksama; dapat disampaikan dalam jumlah karyawan yang banyak dan berada di beberapa lokasi dan sifatnya yang akurat tanpa terjadi penyimpangan pesan.

b. Laporan bulanan, karena atasan memerlukan catatan yang dapat dijadikan sebagai bukti.

Sementara itu, media yang tidak dipilih adalah:

a. Job description, dengan alasan karena atasan tidak memerlukan umpan balik.

b. Memo, dengan alasan bahwa media ini tidak dapat menjangkau sejumlah karyawan sekaligus sehingga tidak dapat memberikan pesan ideologi dengan cepat; kurang akurat sehingga tidak dapat meminimalkan kesalahan penyampaian pesan; serta sifatnya yang tidak terinci rinci, tidak kompleks dan tidak memerlukan perencanaan yang seksama. Alasan lainnya adalah juga bahwa media ini tidak dapat digunakan untuk menyampaikan pesan ideologi jika atasan memerlukan catatan permanen sebagai bukti.

Dipilihnya pedoman kebijaksanaan seperti ditunjukkan di atas sesuai dengan karakteristik pedoman kebijaksanaan yaitu merupakan suatu naskah tertulis yang berisi keterangan tentang berbagai keputusan pimpinan mengenai berbagai masalah yang belum ada peraturan yang timbul pada saat organisasi sedang menjalankan kegiatannya (Bovée \& Thill, 2002, p.484). Selain itu pedoman kebijaksanaan ini juga berfungsi untuk membantu manajer mengkomunikasikan standar perusahaan, membantu mengimplementasikan kebijakan dan prosedur, memonitor dan mengendalikan operasi (Bovée \& Thill, 2002, p. 476).

Selanjutnya, laporan bulanan merupakan media yang juga dipilih penggunaannya untuk menyampaikan pesan ideologi karena dapat dijadikan catatan permanen sebagai bukti dan rinci, bersifat kompleks dan memerlukan perencanaan dengan 
seksama dalam hal memberikan semangat kerja dan rasa tanggung jawab dengan memotivasi karyawan. Hal ini karena di dalam laporan bulanan yang disusun oleh perusahaan merupakan laporan bulanan yang berisikan laporan keseluruhan aktivitas perusahaan. Oleh karena itu, perusahaan biasanya akan menggunakannya untuk melakukan evaluasi dan menyampaikan pesan tugas-tugas yang harus dilakukan oleh karyawan untuk perbaikan penjualan di masa yang akan datang. Bovee dan Thill (2003) mengungkapkan bahwa laporan tertulis pada umumnya lebih panjang dan lebih formal dibandingkan surat dan memo, serta merupakan dokumen faktual dan objektif yang mungkin didistribusikan kepada orang dalam atau luar, tergantung pada tujuan dan subjeknya (p.124). Dengan demikian, jika atasan ingin mengembangkan rasa memiliki tugas dan pertisipasi dalam diri karyawannya dengan catatan permanen sebagai bukti maka penggunaan laporan bulanan merupakan pilihan yang tepat karena sifat formalitasnya yang diarsipkan sehingga akan mudah bagi karyawan untuk menggunakannya sebagai landasan pengembangan tugas selanjutnya karena dapat dibuka dan dibaca sewaktu-waktu.

Sementara itu, media yang paling tidak disarankan untuk mengembangkan rasa memiliki tugas dan partisipasi karyawan adalah penggunaan job description karena atasan tidak memerlukan umpan balik. Hal ini karena job description merupakan informasi tertulis yang menguraikan tugas dan tanggung jawab, kondisi pekerjaan, hubungan pekerjaan dan aspek-aspek pekerjaan pada suatu jabatan tertentu dalam organisasi (Hasibuan, 2006, p. 33), akan tetapi media ini kurang tepat jika atasan ingin mengembangkan rasa memiliki tugas dan partisipasi pada diri karyawan tanpa memerlukan umpan balik secara langsung dari karyawan menurut Hasibuan (2006) uraian pekerjaan yang kurang jelas akan mengakibatkan karyawan kurang mengetahui tugas dan tanggung jawabnya. Hal ini mengakibatkan pekerjaan tidak beres, bahkan pejabat yang bersangkutan menjadi overacting (p.33). Sebagaimana yang dikatakan oleh salah seorang responden bahwa job description di perusahaan memang berisikan tugas-tugas dan tanggung jawab masing-masing karyawan berdasarkan divisi/departemen tetapi rincian tugas-tugas ini tidak up to date artinya, tidak mengikuti perkembangan dari tugas yang sebenarnya hanya dasar pekerjaan yang harus dilakukan dan karyawan tidak bisa hanya terpaku pada itu saja tetapi harus bisa mengembangkan tugas mereka dan berpartisipasi lebih apabila mereka ingin maju selangkah dari pada yang lain.

Media yang juga tidak dipilih karyawan adalah memo. Hal ini karena dengan sifatnya yang sederhana tersebut, menjadikan memo tidak tepat jika digunakan untuk menyampaikan pesan instruksi tugas jika instruksi tugas tersebut harus disimpan sebagai bukti; disampaikan kepada karyawan dalam jumlah yang banyak dan berada di beberapa lokasi; untuk meminimalkan terjadinya penyimpangan pesan; rinci, kompleks dan memerlukan perencanaan dengan seksama serta dalam hal memberikan semangat dan rasa tanggung jawab pada diri karyawan, atasan masih memerlukan umpan balik dari bawahannya. 
Tabel 9. Media Komunikasi Tulisan pada Downward Communication untuk Tujuan Informasi yang Dipilih dan Tidak Dipilih Karyawan

\begin{tabular}{|c|c|c|c|}
\hline Tujuan & $\begin{array}{c}\text { Peringkat } \\
\text { media }\end{array}$ & Nama media & Alasan \\
\hline \multirow[t]{4}{*}{$\begin{array}{l}\text { Menginformasikan } \\
\text { peraturan } \\
\text { organisasi }\end{array}$} & $\begin{array}{l}\text { Media } \\
\text { paling } \\
\text { digunakan }\end{array}$ & $\begin{array}{l}\text { Pedoman } \\
\text { Kebijaksanaan }\end{array}$ & $\begin{array}{l}\text { Tidak memerlukan umpan } \\
\text { balik } \\
\text { Rinci, sifatnya kompleks } \\
\text { dan memerlukan } \\
\text { perencanaan yang seksama } \\
\text { Memerlukan catatan yang } \\
\text { dapat dijadikan sebagai } \\
\text { bukti }\end{array}$ \\
\hline & & $\begin{array}{l}\text { Laporan } \\
\text { bulanan }\end{array}$ & $\begin{array}{l}\text { Disampaikan dalam jumlah } \\
\text { karyawan yang banyak dan } \\
\text { berada di beberapa lokasi } \\
\text { Akurat tanpa terjadi } \\
\text { penyimpangan pesan }\end{array}$ \\
\hline & $\begin{array}{l}\text { Media } \\
\text { paling } \\
\text { tidak } \\
\text { digunakan }\end{array}$ & Memo & $\begin{array}{l}\text { Tidak memerlukan umpan } \\
\text { balik } \\
\text { Memerlukan catatan yang } \\
\text { dapat dijadikan sebagai } \\
\text { bukti } \\
\text { Akurat tanpa terjadi } \\
\text { penyimpangan pesan }\end{array}$ \\
\hline & & Job description & $\begin{array}{l}\text { Rinci, sifatnya kompleks } \\
\text { dan memerlukan } \\
\text { perencanaan yang seksama } \\
\text { Disampaikan dalam jumlah } \\
\text { karyawan yang banyak dan } \\
\text { berada di beberapa lokasi }\end{array}$ \\
\hline $\begin{array}{l}\text { Menginformasikan } \\
\text { data-data dan } \\
\text { kebiasaan } \\
\text { organisasi }\end{array}$ & $\begin{array}{l}\text { Media } \\
\text { paling } \\
\text { digunakan }\end{array}$ & $\begin{array}{l}\text { Laporan } \\
\text { bulanan }\end{array}$ & $\begin{array}{l}\text { Tidak memerlukan umpan } \\
\text { balik } \\
\text { Memerlukan catatan yang } \\
\text { dapat dijadikan sebagai } \\
\text { bukti } \\
\text { Akurat tanpa terjadi } \\
\text { penyimpangan pesan } \\
\text { Rinci, sifatnya kompleks } \\
\text { dan memerlukan } \\
\text { perencanaan yang seksama } \\
\text { Disampaikan dalam jumlah } \\
\text { karyawan yang banyak dan } \\
\text { berada di beberapa lokasi }\end{array}$ \\
\hline
\end{tabular}




\begin{tabular}{llll}
\hline Tujuan & $\begin{array}{c}\text { Peringkat } \\
\text { media }\end{array}$ & Nama media & \multicolumn{1}{c}{ Alasan } \\
\hline Media & Memo & Tidak memerlukan umpan \\
paling & & balik \\
tidak & Job description & $\begin{array}{l}\text { Memerlukan catatan yang } \\
\text { dapat dijadikan sebagai }\end{array}$ \\
& bukti \\
& & Akurat tanpa terjadi \\
& penyimpangan pesan \\
& & Rinci, sifatnya kompleks \\
& dan memerlukan peren- \\
& canaan yang seksama \\
& & Disampaikan dalam jumlah \\
& & karyawan yang banyak dan \\
& & berada di beberapa lokasi \\
\hline
\end{tabular}

Sumber : Data Primer, Panduan Pertanyaan

Hasil di atas menunjukkan bahwa media komunikasi tulisan yang dipilih oleh karyawan dalam pelaksanaan downward communication untuk tujuan informasi yaitu:

I. Untuk menginformasikan peraturan organisasi adalah:

a. Pedoman kebijaksanaan, karena tidak memerlukan umpan balik; penyampaian pesan informasi tersebut dapat dilakukan rinci, sifatnya kompleks dan memerlukan perencanaan yang seksama dan memerlukan catatan yang dapat dijadikan sebagai bukti.

b. Laporan bulanan untuk menginformasikan peraturan organisasi, dengan faktor pendorongnya adalah karena dapat disampaikan dalam jumlah karyawan yang banyak dan berada di beberapa lokasi serta sifatnya yang akurat tanpa terjadi penyimpangan pesan.

II. Menginformasikan data-data dan kebiasaan organisasi yang berhubungan dengan kerja karyawan dipilih laporan bulanan karena tidak memerlukan umpan balik; penyampaian pesan informasi tersebut dapat dilakukan rinci, sifatnya kompleks dan memerlukan perencanaan yang seksama; memerlukan catatan yang dapat dijadikan sebagai bukti; dapat disampaikan dalam jumlah karyawan yang banyak dan berada di beberapa lokasi serta sifatnya yang akurat tanpa terjadi penyimpangan pesan.

Sementara itu, media yang tidak dipilih;

I. Untuk menginformasikan peraturan organisasi adalah:

a. Memo, dengan alasan karena atasan tidak memerlukan umpan balik; memerlukan catatan yang dapat dijadikan sebagai bukti dan kurang akurat sehingga tidak dapat meminimalkan kesalahan dalam penyampaian pesan.

b. Job description, dengan alasan bahwa media ini sifatnya yang tidak terinci; tidak kompleks dan tidak memerlukan perencanaan yang seksama; catatan yang dapat dijadikan sebagai bukti dan kurang akurat sehingga tidak dapat meminimalkan kesalahan dalam penyampaian pesan dan tidak dapat disampaikan dalam jumlah karyawan yang banyak dan berada di beberapa lokasi. 
II. Menginformasikan data-data dan kebiasaan organisasi adalah:

a. Memo, jika alasannya karena atasan tidak memerlukan umpan balik.

b. Job description, dengan alasan bahwa media ini memerlukan catatan yang dapat dijadikan sebagai bukti; kurang akurat sehingga tidak dapat meminimalkan kesalahan dalam penyampaian pesan sifatnya yang tidak terinci; tidak kompleks dan tidak memerlukan perencanaan yang seksama; catatan yang dapat dijadikan sebagai bukti dan kurang akurat sehingga tidak dapat meminimalkan kesalahan dalam penyampaian pesan dan tidak dapat disampaikan dalam jumlah karyawan yang banyak dan berada di beberapa lokasi.

Alasan yang dikemukakan berkaitan dengan penggunaan pedoman kebijaksanaan di atas sesuai dengan karakteristiknya yaitu suatu naskah tertulis yang berisi keterangan tentang berbagai keputusan pimpinan mengenai berbagai masalah yang belum ada peraturan yang timbul pada saat organisasi sedang menjalankan kegiatannya (Bovée \& Thill, 2002, p.484). Dengan demikian, pedoman kebijaksanaan yang bersifat formal ini dapar dijadikan catatan sebagai bukti karena dapat dibaca berulang-ulang oleh siapa pun yang perlu mengetahui isu tertentu. Berdasarkan hasil diskusi lebih lanjut terungkap bahwa pedoman kebijaksanaan ini merupakan panduan bagi karyawan yang mengatur tentang peraturan organisasi dan karyawan dapat melihat dan membacanya berulang-ulang serta dapat diarsipkan sebagai pedoman yang dapat menunjang kerja karyawan.

Selanjutnya, terkait dengan penggunaan laporan bulanan, media ini banyak dipilih karena dapat menyampaikan informasi pada karyawan dalam jumlah banyak serta berada di beberapa lokasi dan sifatnya yang akurat tanpa terjadi penyimpangan pesan. Bovée dan Thill (2003) juga mengungkapkan bahwa sebagaimana dengan tujuan laporan secara umum, di mana salah satunya adalah untuk mengimplementasikan kebijakan dan prosedur yang menjelaskan tentang posisi perusahaan (p.477), sehingga pihak penyampai laporan harus mempersiapkan beberapa hal sesuai dengan tujuannya yaitu akurat, lengkap, dan tidak bias (p.476). Dengan akurasi, kelengkapan, dan ketidakbiasan tersebut maka laporan bulanan akan dapat menjadi media penyampai pesan yang tidak banyak mengandung penyimpangan pesan. Dengan demikian, jika atasan ingin menyampaikan pesan informasi mengenai data-data dan kebiasaan organisasi yang berhubungan dengan kerja karyawan dengan faktor pendorongnya adalah tidak memerlukan umpan balik; penyampaian pesan informasi tersebut dapat dilakukan rinci, sifatnya kompleks dan memerlukan perencanaan yang seksama; memerlukan catatan yang dapat dijadikan sebagai bukti; dapat disampaikan dalam jumlah karyawan yang banyak dan berada di beberapa lokasi serta sifatnya yang akurat tanpa terjadi penyimpangan pesan maka penggunaan laporan bulanan merupakan pilihan yang tepat.

Sementara itu, memo merupakan media yang paling tidak dipilih untuk menyampaikan pesan informasi mengenai peraturan organisasi oleh atasan karena memo tidak dapat dijadikan sebagai bukti serta sifatnya yang kurang akurat sehingga tidak dapat meminimalkan kesalahan dalam penyampaian pesan. Selain itu memo merupakan dokumen yang relatif pendek, pada umumnya satu atau dua halaman dan digunakan untuk pertukaran informasi rutin sehari-hari dalam sebuah organsasi (Bovée \& Thill, 2003, p.122). Dengan demikian, memo hanya digunakan untuk menyampaikan tugas rutin dan sifatnya sederhana serta menjangkau 
karyawan dalam jumlah yang tidak terlalu banyak karena sifatnya yang sederhana. Memo bersifat informal dan menggunakan bahasa percakapan sehari-hari. Sebagaimana diungkapkan oleh Bovée \& Thill (2003) bahwa memo merupakan media yang menggunakan format sederhana untuk menekankan kebutuhan pembaca yang kemungkinan hanya mempunyai waktu terbatas untuk membaca sepintas pesan tersebut (p.122). Selain itu memo hanya membahas satu topik dan kurang bersifat pribadi dibandingkan surat karena konstruksinya yang terbuka dan menggunakan nada percakapan sehingga metode penyampaiannya bersifat informal (p.123). Dengan demikian penggunaan memo kurang tepat apabila digunakan untuk menginformasikan peraturan organisasi tanpa memerlukan umpan balik langsung karena sifatnya yang sederhana dan informal sehingga hanya mempunyai waktu terbatas untuk membaca sepintas pesan tersebut.

Selanjutnya job description tidak dipilih penggunaannya untuk tujuan pesan informasi karena media ini sifatnya yang tidak terinci; tidak kompleks dan tidak memerlukan perencanaan yang seksama dan tidak dapat disampaikan dalam jumlah karyawan yang banyak dan berada di beberapa lokasi. Hal ini karena menurut Hasibuan (2006) bahwa deskripsi pekerjaan adalah informasi tertulis yang menguraikan tugas dan tanggung jawab, kondisi pekerjaan, hubungan pekerjaan dan aspek-aspek pekerjaan pada suatu jabatan tertentu dalam organisasi (p.33) sehingga tidak tercantum peraturan organisasi secara rinci, kompleks dan memerlukan perencanaan seksama.

Tabel 10. Media Komunikasi Tulisan pada Downward Communication untuk Tujuan Balikan yang Dipilih dan Tidak Dipilih Karyawan

\begin{tabular}{llll}
\hline \multicolumn{1}{c}{ Tujuan } & $\begin{array}{c}\text { Peringkat } \\
\text { media }\end{array}$ & Nama media & \multicolumn{1}{c}{ Alasan } \\
\hline $\begin{array}{l}\text { Pemberian } \\
\text { evaluasi }\end{array}$ & Media & Laporan & Tidak memerlukan umpan \\
masukan & yang & bulanan & balik \\
tugas & dipilih & & $\begin{array}{l}\text { Rinci, sifatnya kompleks } \\
\text { dan memerlukan }\end{array}$ \\
& & & perencanaan yang seksama \\
& & Memerlukan catatan yang \\
& & dapat dijadikan bukti \\
& & Disampaikan dalam jumlah \\
& & & karyawan yang banyak dan \\
& & & berada di beberapa lokasi \\
& & & Akurat tanpa terjadi \\
& & penyimpangan pesan \\
& Media & Job description & Tidak memerlukan umpan \\
& tidak & & balik \\
& dipilih & & Rinci, sifatnya kompleks \\
& & dan memerlukan \\
& & perencanaan yang seksama \\
& & Memerlukan catatan yang \\
& & dapat dijadikan bukti \\
& & Disampaikan dalam jumlah \\
\hline
\end{tabular}




\begin{tabular}{|c|c|c|c|}
\hline Tujuan & $\begin{array}{l}\text { Peringkat } \\
\text { media }\end{array}$ & Nama media & Alasan \\
\hline $\begin{array}{l}\text { Pemberian } \\
\text { panghargaan atas } \\
\text { prestasi karyawan }\end{array}$ & $\begin{array}{l}\text { Media } \\
\text { yang } \\
\text { dipilih }\end{array}$ & $\begin{array}{l}\text { Laporan } \\
\text { bulanan }\end{array}$ & $\begin{array}{l}\text { karyawan yang banyak dan } \\
\text { berada di beberapa lokasi } \\
\text { Akurat tanpa terjadi } \\
\text { penyimpangan } \\
\text { Tidak memerlukan umpan } \\
\text { balik } \\
\text { Rinci, sifatnya kompleks } \\
\text { dan memerlukan } \\
\text { perencanaan yang seksama } \\
\text { Memerlukan catatan yang } \\
\text { dapat dijadikan bukti } \\
\text { Disampaikan dalam jumlah } \\
\text { karyawan yang banyak dan } \\
\text { berada di beberapa lokasi } \\
\text { Akurat tanpa terjadi } \\
\text { penyimpangan pesan } \\
\text { Tidak memerlukan umpan } \\
\text { balik } \\
\text { Rinci, sifatnya kompleks } \\
\text { dan memerlukan } \\
\text { perencanaan yang seksama } \\
\text { Memerlukan catatan yang } \\
\text { dapat dijadikan bukti } \\
\text { Disampaikan dalam jumlah } \\
\text { karyawan yang banyak dan } \\
\text { berada di beberapa lokasi } \\
\text { Akurat tanpa terjadi } \\
\text { penyimpangan }\end{array}$ \\
\hline
\end{tabular}

Sumber: Data Primer, Panduan Pertanyaan

Tabel di atas menunjukkan bahwa media komunikasi tulisan yang dipilih karyawan dalam pelaksanaan downward communication untuk tujuan balikan adalah laporan bulanan, karena tidak memerlukan umpan balik; rinci, sifatnya kompleks dan memerlukan perencanaan yang seksama; memerlukan catatan yang dapat dijadikan sebagai bukti; dapat disampaikan dalam jumlah karyawan yang banyak dan berada di beberapa lokasi dan sifatnya yang akurat tanpa terjadi penyimpangan pesan. Sebagaimana diungkapkan oleh Bovee dan Thill (2003) bahwa tujuan laporan secara umum salah satunya adalah untuk mengimplementasikan kebijakan dan prosedur yang menjelaskan tentang posisi perusahaan (p. 477), sehingga pihak penyampai laporan harus mempersiapkan beberapa hal sesuai dengan tujuannya yaitu akurat, lengkap, dan tidak bias (p.476). Dengan akurasi, kelengkapan, dan ketidakbiasan tersebut maka laporan bulanan akan dapat menjadi media penyampai pesan yang tidak banyak mengandung penyimpangan pesan. Dengan demikian, jika atasan ingin menyampaikan pesan balikan kepada karyawan 
yang disampaikan secara rinci dan dengan pertimbangan yang seksama; tidak memerlukan umpan balik; dapat disampaikan dalam jumlah karyawan yang banyak dan berada di beberapa lokasi dan sifatnya yang akurat tanpa terjadi penyimpangan pesan maka penggunaan laporan bulanan merupakan pilihan yang tepat. Melalui laporan bulanan juga, atasan dapat memberikan pesan balikan ini dengan catatan permanen sebagai bukti maka penggunaan laporan bulanan merupakan pilihan yang tepat karena sifat formalitasnya yang dapat dijadikan sebagai bukti mengenai pesan balikan. Selain itu, laporan bulanan juga dapat diarsipkan sehingga dapat dibuka dan dibaca sewaktu-waktu.

Sementara itu, media yang tidak dipilih karyawan adalah job description, dengan alasan karena atasan masih memerlukan umpan balik; sifatnya yang tidak terinci, tidak kompleks; tidak dapat dijadikan sebagai bukti; tidak dapat menjangkau sejumlah karyawan sekaligus sehingga tidak dapat memberikan pesan balikan dengan cepat dan kurang akurat sehingga tidak dapat meminimalkan penyampaian pesan. Hal ini dikuatkan oleh Hasibuan (2006) bahwa deskripsi pekerjaan adalah informasi tertulis yang menguraikan tugas dan tanggung jawab, kondisi pekerjaan, hubungan pekerjaan dan aspek-aspek pekerjaan pada suatu jabatan tertentu dalam organisasi (p.33).

\section{KESIMPULAN}

Ketika menyelenggarakan downward communication perusahaan menggunakan media komunikasi berupa media lisan dan tulisan. Di dalam penggunaannya tersebut karyawan memiliki alasan atau faktor pendorong yang melatarbelakanginya. Faktor-faktor yang mendorong karyawan dalam menggunakan media komunikasi lisan pada downward communication diantaranya adalah adanya umpan balik langsung, singkat dan mudah diterima serta tidak memerlukan catatan permanen. Untuk alasan ini, media komunikasi yang dipilih karyawan adalah telepon dan laporan lisan, media telepon paling tepat digunakan untuk tujuan instruksi tugas yaitu mendelegasikan tugas dan mengarahkan tugas kepada karyawan sedangkan media laporan lisan digunakan untuk tujuan pesan balikan yaitu evaluasi dan penghargaan atas prestasi karyawan.

Media komunikasi lain yang dipilih karyawan dengan alasan agar dapat menjangkau banyak karyawan, cepat, adanya umpan balik langsung, serta mendorong interaksi antar karyawan adalah rapat, media ini paling tepat digunakan untuk tujuan instruksi tugas yaitu mendelegasikan tugas dan mengarahkan tugas kepada karyawan juga untuk pesan balikan yaitu dalam memberikan evaluasi dan penghargaan prestasi kepada karyawan serta untuk tujuan rasional ideologi dan informasi. Sementara kontak interpersonal juga menjadi media yang dipilih karyawan untuk tujuan rasional, ideologi, informasi, dan mendapatkan balikan karena pesan dapat disampaikan dengan singkat dan mudah.

Pilihan karyawan dalam menggunakan media komunikasi pada downward communication dalam bentuk tulisan untuk alasan dibutuhkannya catatan permanen dan tidak membutuhkan umpan balik secara langsung serta digunakan untuk tujuan instruksi tugas adalah memo. Sementara untuk alasan dipilihnya media karena dapat disampaikan kepada karyawan dalam jumlah banyak, berada di 
beberapa lokasi, bersifat rinci, sifatnya kompleks dan memerlukan perencanaan yang seksama adalah job description.

Penggunaan media komunikasi pada downward communication secara tulisan untuk tujuan instruksi tugas, rasional, ideologi, informasi, dan balikan karena tidak memerlukan umpan balik, rinci, sifatnya kompleks dan memerlukan perencanaan yang seksama; memerlukan catatan yang dapat dijadikan bukti; disampaikan dalam jumlah karyawan yang banyak dan berada di beberapa lokasi dan akurat tanpa terjadi penyimpangan pesan adalah adalah laporan bulanan.

Sementara untuk kebutuhkan keakuratan tanpa terjadi penyimpangan pesan dan dapat disampaikan dalam jumlah karyawan yang banyak dan berada di beberapa lokasi, tidak memerlukan umpan balik, memerlukan catatan yang dapat dijadikan sebagai bukti, rinci, sifatnya kompleks dan memerlukan perencanaan yang seksama dipilih pedoman kebijaksanaan untuk tujuan pesan instruksi tugas, rasional, ideologi dan informasi.

\section{DAFTAR PUSTAKA}

Bovée, Courtland. L., \& Thill, John. V. 2007. Excellence in business communication. USA: Pearson Education.

Cultip, Scott. M., Center, Allen. H., \& Broom, Glen. M. 2005. Efektif public relations. Jakarta: PT. Indeks Kelompok Gramedia.

Curtis, Dan. B., Floyd, James. J., Winsor, Jerry. L. 2004. Komunikasi bisnis dan profesional. Bandung: PT. Remaja Rosdakarya Offset.

Hasibuan, H. Malayu. S.P. 2006. Manajemen sumber daya manusia. Jakarta: PT. Bumi Aksara.

Jiwanto, Gunawan. 1985. Komunikasi dalam organisasi. Yogyakarta: Andi Offset.

Jefkins, Frank. 1992. Hubungan masyarakat. Jakarta: Intermasa.

Ludlow, Ron., \& Panton, Fergus. 2000. Komunikasi efektif. Yogyakarta: Andi.

Muhammad, Arni. 2005. Komunikasi organisasi. Jakarta: Bumi Aksara.

O'Rourke, James S, IV. 2001. Management communication: A case-analysis approach ( $1^{\text {st }}$ ed.). Upper Saddle River, New Jersey: Prentice Hall.

Pace, Wayne., \& Faules, Don. 2002. Komunikasi organisasi. Bandung: PT Remaja Rosdakarya.

Panuju, Redi. 2001. Komunikasi organisasi. Yogyakarta: Pustaka Pelajar.

Pareek, Udai. 1984. Perilaku organisasi. Jakarta: PT. Pustaka Binamann Pressindo.

Sunarto. 2005. Komunikasi perkantoran. Yogyakarta: Media Wacana.

Suprihanto, John., Harsiwi, TH. Agung M., \& Hadi, Prakosa. 2003. Perilaku organisasional. Yogyakarta: Sekolah Tinggi Ilmu Ekonomi YKPN. 
Sutarto. 2002. Dasar-dasar organisasi. Yogyakarta: Gadjah Mada University Press.

Thoha, Miftah. 2005. Perilaku organisasi. Jakarta: PT. Raja Grafindo Persada.

Tyson, Shawn., \& Jackson, Tony. 2000. Perilaku organisasi. Yogyakarta: Andi Offset.

Tubbs, Stewart. L., \& Moss, Sylvia. 2000. Human communication. Bandung: PT. Remaja Rosdakarya.

Tucker, Kerry., Derelian, Doris., \& Rouner, Donna. 1997. Public relations writing. New Jersey: Pretince Hall.

Wexley, Kenneth. N., \& Yuki, Gary. A. 2005. Perilaku organisasi dan psikologi personalia. Jakarta: PT. Rineka Cipta.

Walsh, Frank. 1986. Public relations writer in a computer age. New Jersey: Pretince Hall.

Wilcox, Dennis. L. 2005. Public relations writing and media techniques. United States: Pearson Education 